\title{
Characteristics of Water Vapor in the UTLS over the Tibetan Plateau Based on AURA/MLS Observations
}

\author{
Yi Sun, ${ }^{1}$ Quanliang Chen, ${ }^{1}$ Ke Gui, ${ }^{2}$ Fangyou Dong, ${ }^{3}$ Xiao Feng, ${ }^{1}$ and Qichao Long ${ }^{4}$ \\ ${ }^{1}$ College of Atmospheric Science, Chengdu University of Information Technology and Plateau Atmospheric \\ and Environment Laboratory of Sichuan Province, Chengdu 610225, China \\ ${ }^{2}$ State Key Laboratory of Severe Weather (LASW) and Institute of Atmospheric Composition, \\ Chinese Academy of Meteorological Sciences, Beijing 100081, China \\ ${ }^{3}$ Anqing Meteorological Bureau, Anqing 246003, China \\ ${ }^{4}$ Sichuan Academy of Environmental Sciences, Chengdu 610041, China
}

Correspondence should be addressed to Quanliang Chen; chenql@cuit.edu.cn

Received 26 April 2017; Accepted 28 June 2017; Published 31 July 2017

Academic Editor: Dong Guo

Copyright (C) 2017 Yi Sun et al. This is an open access article distributed under the Creative Commons Attribution License, which permits unrestricted use, distribution, and reproduction in any medium, provided the original work is properly cited.

\begin{abstract}
Water vapor (WV) has a vital effect on global climate change. Using satellite data observed by AURA/MLS and ERA-Interim reanalysis datasets, the spatial distributions and temporal variations of WV were analyzed. It was found that high WV content in the UTLS over the southern Tibetan Plateau is more apparent in summer, due to monsoon-induced strong upward motions. The $\mathrm{WV}$ content showed the opposite distribution at $100 \mathrm{hPa}$, though, during spring and winter. And a different distribution at $121 \mathrm{hPa}$ indicated that the difference in WV content between the northern and southern plateau occurs between 121 and $100 \mathrm{hPa}$ in spring and between 147 and $121 \mathrm{hPa}$ in winter. In the UTLS, it diminishes rapidly with increase in altitude in these two seasons, and it shows a "V" structure in winter. There has been a weak increasing trend in WV at $100 \mathrm{hPa}$, but a downtrend at 147 and $215 \mathrm{hPa}$, during the past 12 years. At the latter two heights, the WV content in summer has been much higher than in other seasons. Furthermore, WV variation showed a rough wave structure in spring and autumn at $215 \mathrm{hPa}$. The variation of WV over the Tibetan Plateau is helpful in understanding the stratosphere-troposphere exchange (STE) and climate change.
\end{abstract}

\section{Introduction}

Water-as solid, liquid, and gas-is one of the most important components of the earth. The distribution of water vapor (WV) in the atmosphere is concentrated mainly below $500 \mathrm{hPa}$. Above the middle troposphere, including the upper troposphere and the lower stratosphere (UTLS) at $5 \sim 20 \mathrm{~km}$, the water vapor mixing ratio (WVMR) is $2 \sim 4$ times lower than in the lower troposphere. Nevertheless, the radiation force produced by the distribution and transformation of WV in this region can change the energy balance of the earth-atmosphere system, and it can have a vital impact on global climate change $[1,2]$, for two reasons. First, WV is one of the major greenhouse gases, and it has a large influence on the radiation balance. Some studies have shown that the greenhouse effect caused by $\mathrm{WV}$ is twice that of carbon dioxide in the tropical troposphere [1], while on the other hand the refrigeration effect caused by increasing WV and ozone fluctuation is considerable [3]. Secondly, WV is the $\mathrm{OH}$ radical of photochemical reaction in the stratosphere, and it participates in this reaction, exerting an influence on the distribution and variation of ozone in the stratosphere [4], thereby affecting the global climate.

There are two dominating factors determining how much $\mathrm{WV}$ is in the stratosphere. One is the methane oxidation process; about a third of the WV comes from this source [5]. Another important source of stratospheric water vapor is upward transportation from the troposphere, and its transmission path, on the global scale, is considered to be the advection pathway into the high latitudes of the stratosphere from the low latitudes of the equatorial regions [6]. In addition, the variation of WV in the UTLS is affected by 
tropopause temperature and $\mathrm{BD}$ circulation [7] and also related to synoptic scale perturbations $[8,9]$.

Because the extent of global warming is modulated by water vapor feedback, this feedback is acknowledged as the most critical factor in the rate of climate change. There is, however, a great deal of controversy about the WV feedback effects, and exactly how the feedback works is still not entirely clear. Most of the models show that global warming will lead to increased $\mathrm{WV}$ in the upper troposphere and that this increase will further promote climate warming: in other words, WV has a strong positive feedback effect [1013]. However, Lindzen et al. [14-16] have said that global warming would enhance convection and that the cloud tower of convection could extend to higher and colder levels, removing WV from the upper troposphere, and a large amount of emergent long-wave radiation entering space over a wide desiccated sinking area could slow down global warming. Thus, WV could also have a negative feedback effect.

The Tibetan Plateau and its surrounding area may play a crucial role in the process of global stratosphere-troposphere exchange (STE), because of the special geographical features of the plateau. The plateau area, on average, is more than 4000 meters above sea level-about the height of the middle troposphere. It is evident that physical and chemical processes in the UTLS are able to exert influence near the surface of the Tibetan Plateau. Because of the influence of Asian monsoons, the Tibetan Plateau is regarded as a heat source in summer, and strong upward transportation can send lower tropospheric materials up over this region, forming a channel from troposphere to stratosphere, and this transmission mechanism is probably one of the important causes of the ozone valley over the Tibetan Plateau in summer [17]. Some satellite data and model calculations have demonstrated that the Tibetan Plateau is also the upward transmission channel of $\mathrm{WV}$ and atmospheric pollutants $[18,19]$. In addition, massive amounts of $\mathrm{WV}$ are transported by the large-scale circulation and affect the distribution of stratospheric water vapor.

Randel and Park [20] found that anticyclonic circulation and convection coupling had an important influence on the distribution of upper tropospheric chemical compositions during the Asian summer monsoon period, and there was an abnormal distribution of $\mathrm{WV}$ within the anticyclonic circulation, while Jackson et al. [21, 22] pointed out that the highest WV content in the lower stratosphere appeared over the Tibetan Plateau, not over the monsoon regions. Fu et al. [22] also suggested that deep convective activities driven by thermals produced significant impacts on WV movement across the tropopause over the Tibetan Plateau. Evans et al. [23] and Smith et al. [24] demonstrated that increasing stratospheric WV could be explained by strengthened convection during the summer monsoon period over Asia and the Tibetan Plateau. The distribution of atmospheric compositions over the Plateau region has obvious regional characteristics.

Many scholars have discussed the features of $\mathrm{WV}$ and its conveying mechanism in the UTLS, but have focused mainly on the tropics [1, 18, 25-29]. Uma et al. [30], using
Microwave Limb Sounder (MLS) observations, discovered that WV content has shown no significant change in the UTLS of the northern hemisphere monsoon regions during the preceding eight years. Tian et al. [31] found that WVMR in the UTLS over the northern Tibetan Plateau in March and April is relatively higher than over the surrounding regions at the same latitude and also detected that a region of low WV values existed from May to September in the upper troposphere at around $200 \mathrm{hPa}$ over the western Tibetan Plateau. In recent years, some researchers have suggested that the Tibetan Plateau has played a very important role in $\mathrm{WV}$ transportation [32-34]. Therefore, studying the distribution of water vapor content in the UTLS region of the Tibetan Plateau has great significance and could be very helpful in understanding the STE exchange over the plateau and in comprehending the influence of UTLS vapor on the global climate. Because of the complex and rugged plateau terrain, it is difficult to collect data, especially for WV in the upper troposphere, and such study is limited by the distribution and variation of WV in the UTLS over the Tibetan Plateau. Building on previous researches, this study focused on the long-term trends and distributions of WV in the UTLS over the Tibetan Plateau, obtained from the MLS instrument on board the AURA Earth Observing System satellite (EOS).

\section{Data and Methods}

The AURA satellite was launched on 15 July 2004. It has a sunsynchronous orbit at a height of $705 \mathrm{~km}$ at $98^{\circ}$ inclination. The plane of orbit is offset $82^{\circ}$ from the equatorial plane of earth. The horizontal grid of the on-board MLS instrument is every $1.5^{\circ}$, or about $165 \mathrm{~km}$ along the track. The instrument can obtain atmospheric composition data-including $\mathrm{WV}$, carbon monoxide, and ozone-using microwave detection technology. Version 4.2 of Level 2 water vapor data used in this study was derived from the $190 \mathrm{GHz}$ channel, and it is significantly better than the V3.3 or V2.2 [35, 36] data. The MLS observation data are reliable at several different heights, and an effective vertical range from 316 to $0.002 \mathrm{hPa}$ is recommended [35]. The WV vertical resolution is $2.5 \mathrm{~km}$ from 316 to $215 \mathrm{hPa}$ and degrades to $3 \mathrm{~km}$ from 100 to $1 \mathrm{hPa}$. For water vapor, typical single-profile precisions are $0.90 .7,0.5$, and $0.3 \mathrm{ppmv}$ at $215,147,100 \mathrm{hPa}$, and the lower stratosphere, respectively [36]. The period of the data used in the present study was from 2005 to 2016 inclusively. The WV data retrieved from the MLS instrument were validated, as can be seen in Lambert et al. [37] and Schwartz et al. [38].

The European Center for Medium-range Weather Forecast (ECMWF) Re-Analysis Interim data (ERA-Interim), including wind field, temperature, and potential vorticity $(\mathrm{PV})$, were used in this study. The horizontal spatial and temporal resolutions were $0.5^{\circ} \times 0.5^{\circ}$ and one month (over the period 2005 to 2016), respectively. Moreover, the monthly average data from the tropopause came from the National Centre for Environmental Prediction (NCEP) and had a resolution of $2.5^{\circ} \times 2.5^{\circ}$.

Since this study focused on the climatological characteristics of $\mathrm{WV}$ at the seasonal scale over the Tibetan 
Plateau, the seasons were defined based on the northern hemisphere: spring (March, April, and May-MAM), summer (June, July, and August-JJA), autumn (September, October, and November-SON), and winter (December, 2nd January, and 2nd February-DJF). In order to facilitate mapping and analysis, the WVMR data were taken with a resolution of $0.5^{\circ} \times 0.5^{\circ}$ on a latitude-longitude grid.

\section{Results}

3.1. Horizontal Distribution Characteristics of Water Vapor. First, it is necessary to note that heights of 215, 147, and $100 \mathrm{hPa}$ over the Tibetan Plateau were selected to represent the UTLS in this study, partly because the effective height of MLS observations starts at $316 \mathrm{hPa}$ [35], and partly because these three levels correspond to the UTLS region near the tropopause [39]. The height of $215 \mathrm{hPa}$ can be considered the upper troposphere; $147 \mathrm{hPa}$ and the tropopause are equivalent; and $100 \mathrm{hPa}$ is generally located in the lower stratosphere.

Figure 1 shows the spatial distribution of WV in the UTLS region over the Tibetan Plateau at different seasons during 2005-2016. As can be seen from the $215 \mathrm{hPa}$ data (Figures 1(a), 1(b), 1(c), and 1(d)), the WV values in JJA and SON were the highest, and those in DJF and MAM were relatively low. The maximum content in JJA sometimes reached $160 \mathrm{ppmv}$, while the highest in DJF was only 25 ppmv. The seasonal distribution variations of $\mathrm{WV}$ at $147 \mathrm{hPa}$ (Figures 1(e), 1(f), $1(\mathrm{~g})$, and $1(\mathrm{~h})$ ) are consistent with those at $215 \mathrm{hPa}$ : lower in the northern plateau and higher in the southern regions. However, there is a notable difference in the distributions at the $100 \mathrm{hPa}$ height (Figures 1(i), 1(j), 1(k), and 1(l)), compared to those at the other two pressure levels: there is more $\mathrm{WV}$ in the north and less in the south. The zonal averages of WV in UTLS over the plateau at different seasons and heights are shown in Figure 2. The distributions of $\mathrm{WV}$ at $215 \mathrm{hPa}$ (Figures 2(a), 2(b), 2(c), and 2(d)) and $147 \mathrm{hPa}$ (Figures 2(e), 2(f), 2(g), and 2(h)) correspond to those in Figure 1: the WV content decreased with an increase in latitude. But the WV at $100 \mathrm{hPa}$ increased with latitude in DJF and MAM. Chen and Liu [40] pointed out that cirrus clouds occur mainly in winter and spring over the plateau, but are almost completely absent in summer. And Tian et al. [31] indicated that in winter and summer, the $200 \mathrm{hPa}$ air layer was located near and below the tropopause, and that in winter and spring the $100 \mathrm{hPa}$ pressure level was located in the stratosphere, while the tropopause could be uplifted to about $100 \mathrm{hPa}$ by the thermal effect of the Tibetan Plateau in summer.

As mentioned earlier in this section, the WV content in the southern and northern plateau regions showed opposite distributions at $100 \mathrm{hPa}$ versus $147 \mathrm{hPa}$, in MAM and DJF. In order to determine the height of the transition from 100 to $147 \mathrm{hPa}$, Figure 3 shows the distributions of $\mathrm{WV}$ at $121 \mathrm{hPa}$ in MAM and DJF ( $121 \mathrm{hPa}$ is the only level between 100 and $147 \mathrm{hPa}$ detectable by the MLS instrument). As shown in Figure 3(a), the highest value of $\mathrm{WV}$ at $121 \mathrm{hPa}$ in MAM occurred mainly over the southern part of the plateau and was about 5.4 ppmv; the $\mathrm{WV}$ content in the northern regions was less than 3.4 ppmv. However, in Figure 3(b), the WV distribution in DJF was contrary to that in MAM, and the $\mathrm{WV}$ content in the northern plateau was larger than that in the southern region. The difference in $\mathrm{WV}$ distribution, between MAM and DJF at $121 \mathrm{hPa}$ height, indicates that the change in $\mathrm{WV}$ content between the north and south occurs between 121 and $100 \mathrm{hPa}$ in spring, and between 147 and $121 \mathrm{hPa}$ in winter.

From Figures $1(\mathrm{i}), 1(\mathrm{j}), 1(\mathrm{k})$, and $1(\mathrm{l})$, we can see that there is an obvious annual variation in $\mathrm{WV}$ at $100 \mathrm{hPa}$ in the southern plateau, and that the WV content is higher in JJA and lower in DJF. June to August is the development stage of the Asian summer monsoon season, and $100 \mathrm{hPa}$ and $150 \mathrm{hPa}$ correspond to the positions of the tropopause in summer and winter. For this reason, the wind and temperature distributions at 100 and $150 \mathrm{hPa}$ in JJA and DJF are given in Figure 4. It can be seen from Figure 1 that the WV content increased significantly at all heights in summer and that the highest concentrations of $\mathrm{WV}$ occurred in the southwest at $147 \mathrm{hPa}$. Figure 4 shows that the anticyclonic circulations of 100 and $150 \mathrm{hPa}(\mathrm{a}, \mathrm{b})$ in the horizontal wind field are obvious and that the high values of WV on the windward slope of the plateau are mainly transported from the southwestern edge of the plateau, which is evidently affected by the summer monsoons. The development of strong summer monsoons transports abundant WV over the Indian Ocean to the plateau and brings more $\mathrm{WV}$ to the upper troposphere. And at $500 \mathrm{hPa}$ (Figure 5(a)), a cyclonic circulation, although weak, can still be seen over the southern plateau, transforming the Tibetan Plateau to a heat source, forming a "heat pump" that can suck up WV from the surrounding lower atmosphere, so that abundant WV from the Bengal Bay is uplifted to the upper troposphere over the plateau. Because the updrafts occur almost everywhere above the plateau in summer, and at high intensities, when they rise to the UTLS the South Asia High forces the airflow around, creating the STE. At the same time, a WV increase caused by the convective activity gathers over the plateau. Therefore, under the combined action of the deep convection over the Tibetan Plateau and the Indian summer monsoons, the $\mathrm{WV}$ in the troposphere moves upward, leading to an increase in $\mathrm{WV}$ in the lower stratosphere. However, westerly wind prevails over the plateau at 100 (Figure 4(d)), 150 (Figure 4(b)), and $500 \mathrm{hPa}$ (Figure 5(b)), and the plateau is turned into a cold source in winter; the upward air flow weakens and the WV clearly decreases near the tropopause.

3.2. Vertical Distribution Characteristics of Water Vapor. In the troposphere, WV content will decrease rapidly with height; it is about $10^{-2} \mathrm{vmr}\left(1 \mathrm{vmr}=10^{6} \mathrm{ppmv}\right)$ at sea level and $10^{-4} \mathrm{vmr}$ in the desert. There is about $10^{-5} \mathrm{vmr}$ near $200 \mathrm{hPa}$ in the upper troposphere, but the $\mathrm{WV}$ does not always decrease when it arrives in the stratosphere. In this research, the main body of the plateau $\left(28^{\circ} \mathrm{N}-40^{\circ} \mathrm{N}\right.$, $75^{\circ} \mathrm{E}-105^{\circ} \mathrm{E}$ ) was studied. Figure 6 shows the vertical profiles of $\mathrm{WV}$ over the plateau in different seasons. From the WV profile of the spring averages (Figure 6(a)), we can 


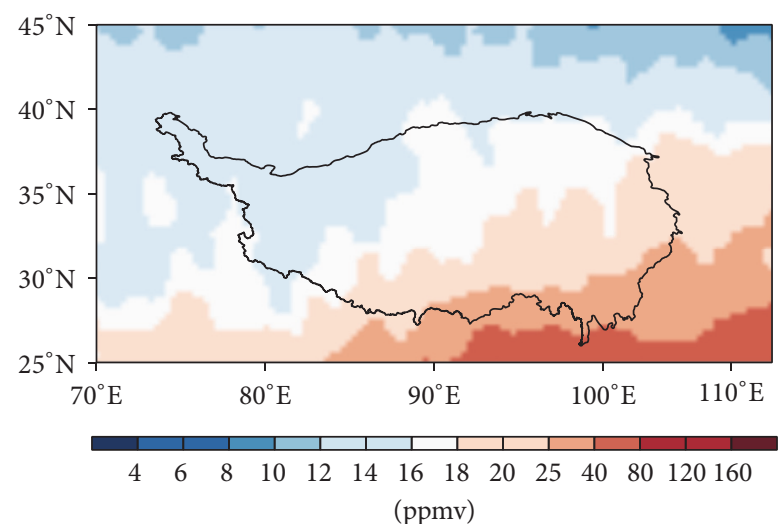

(a) MAM $215 \mathrm{hPa}$

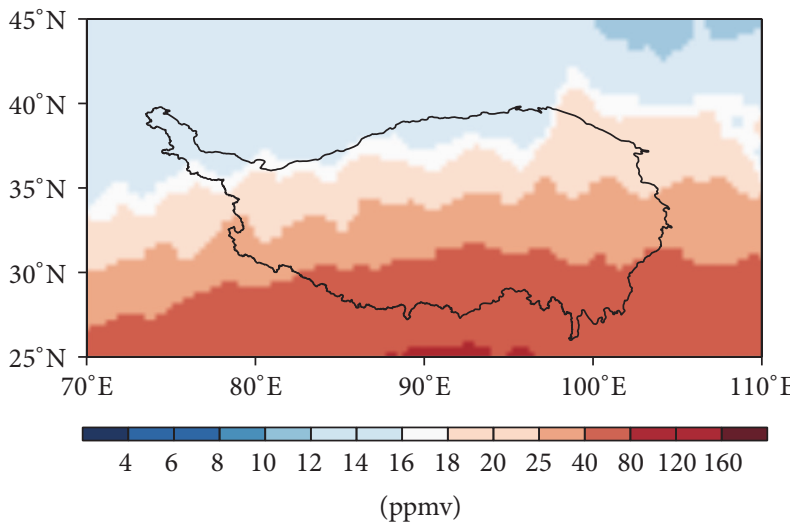

(c) $\mathrm{SON} 215 \mathrm{hPa}$

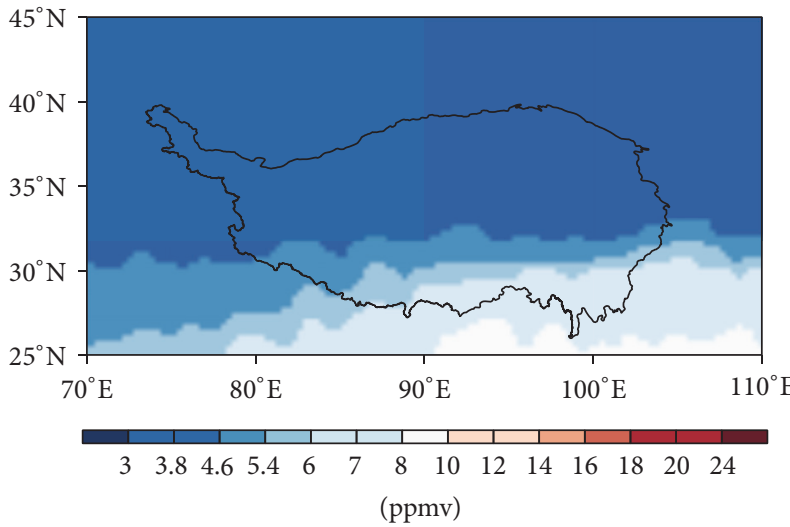

(e) MAM $147 \mathrm{hPa}$

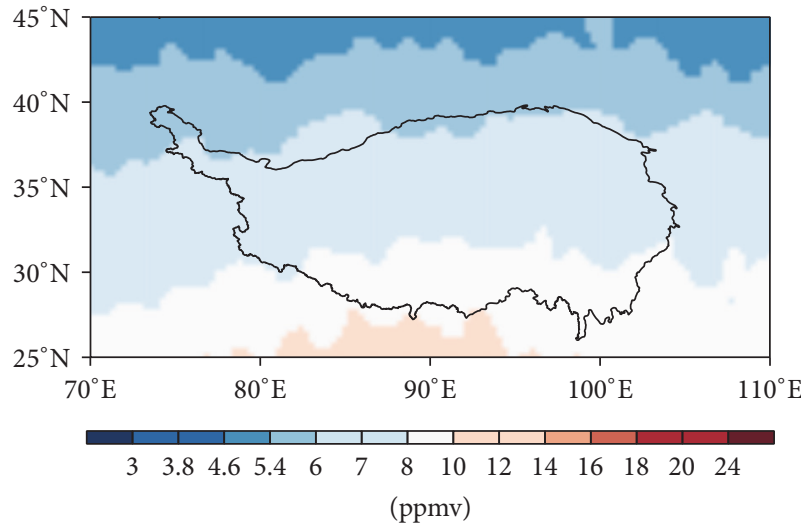

(g) $\mathrm{SON} 147 \mathrm{hPa}$

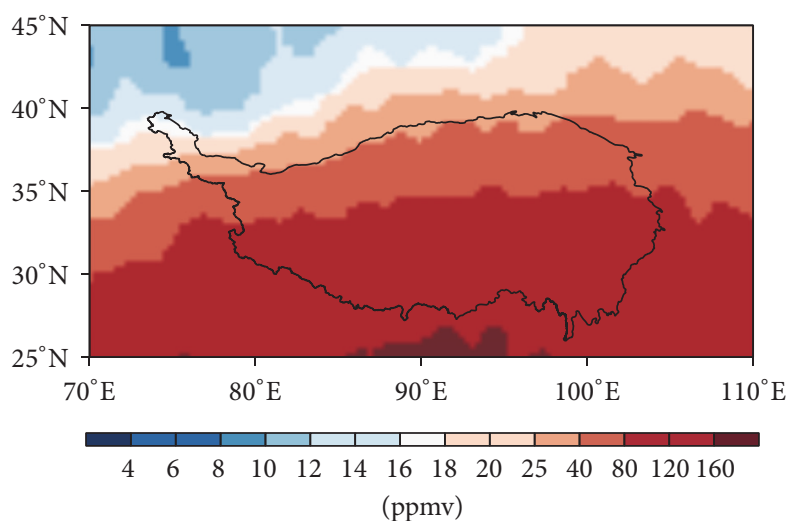

(b) JJA $215 \mathrm{hPa}$

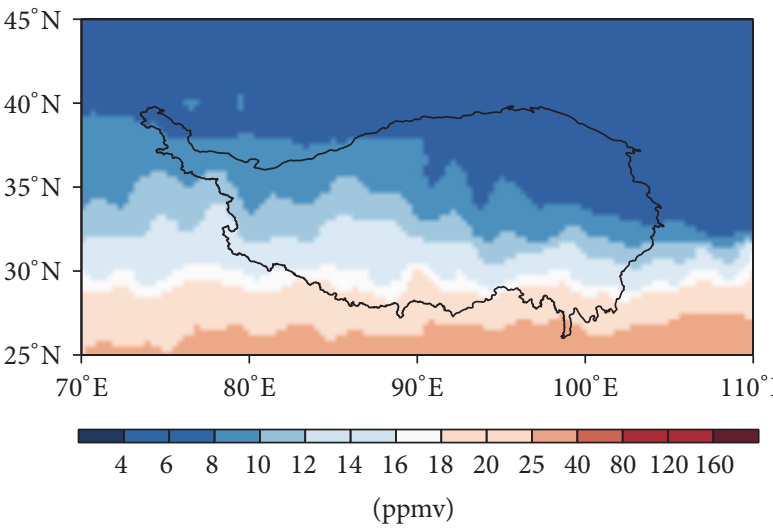

(d) DJF $215 \mathrm{hPa}$

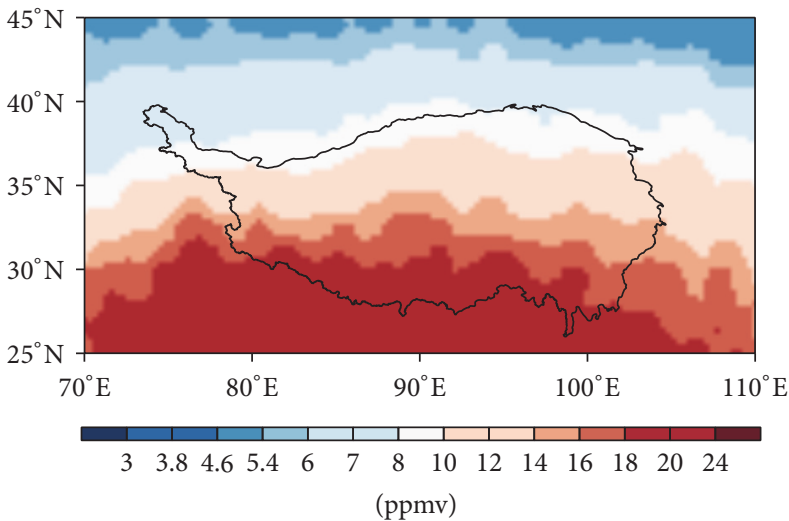

(f) JJA $147 \mathrm{hPa}$

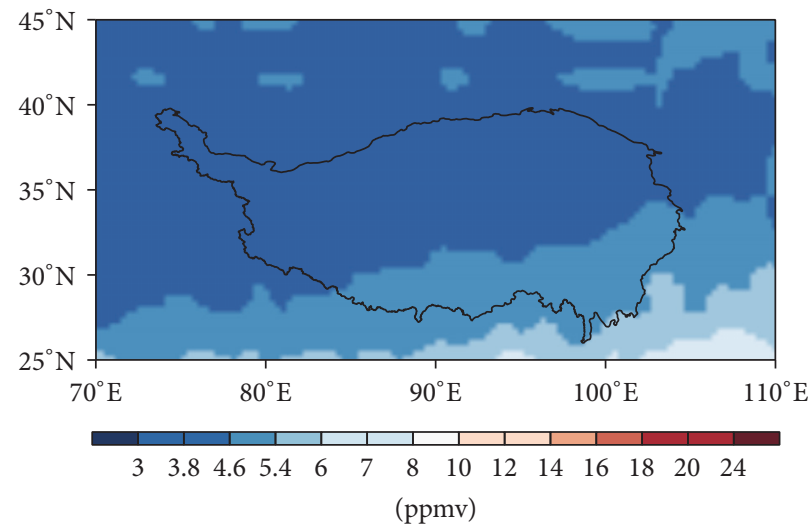

(h) DJF $147 \mathrm{hPa}$

FIgure 1: Continued. 


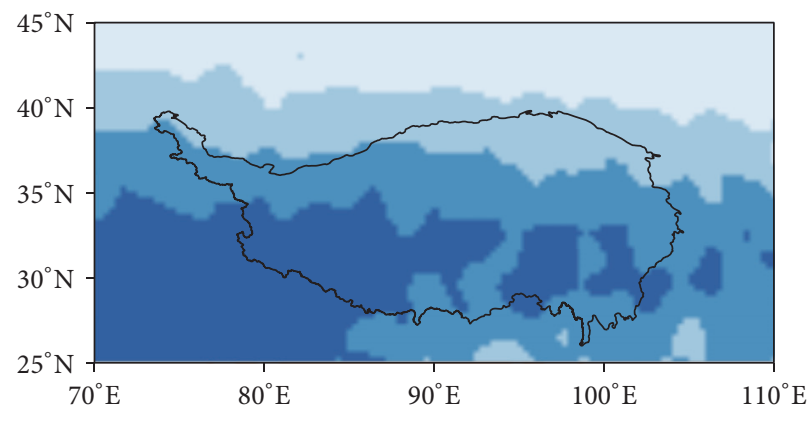

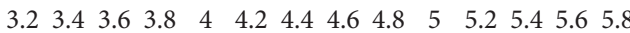
(ppmv)

(i) MAM $100 \mathrm{hPa}$

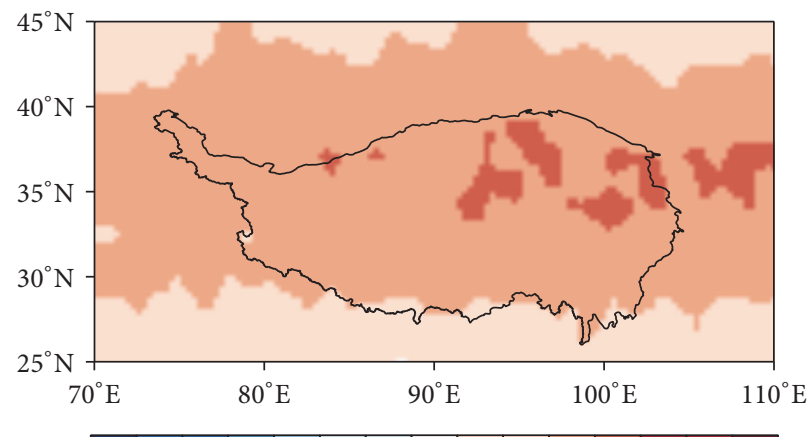

$\begin{array}{llllllllllllll}3.2 & 3.4 & 3.6 & 3.8 & 4 & 4.2 & 4.4 & 4.6 & 4.8 & 5 & 5.2 & 5.4 & 5.6 & 5.8\end{array}$ (ppmv)

(k) SON $100 \mathrm{hPa}$

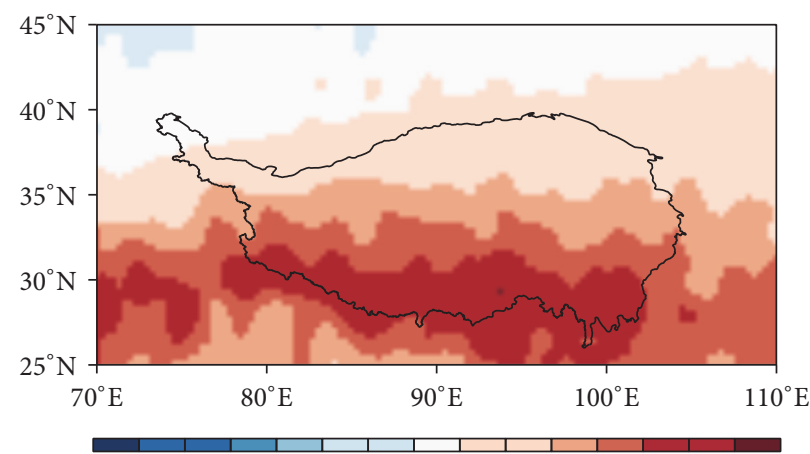

$\begin{array}{llllllllllllll}3.2 & 3.4 & 3.6 & 3.8 & 4 & 4.2 & 4.4 & 4.6 & 4.8 & 5 & 5.2 & 5.4 & 5.6 & 5.8\end{array}$

(ppmv)

(j) JJA $100 \mathrm{hPa}$

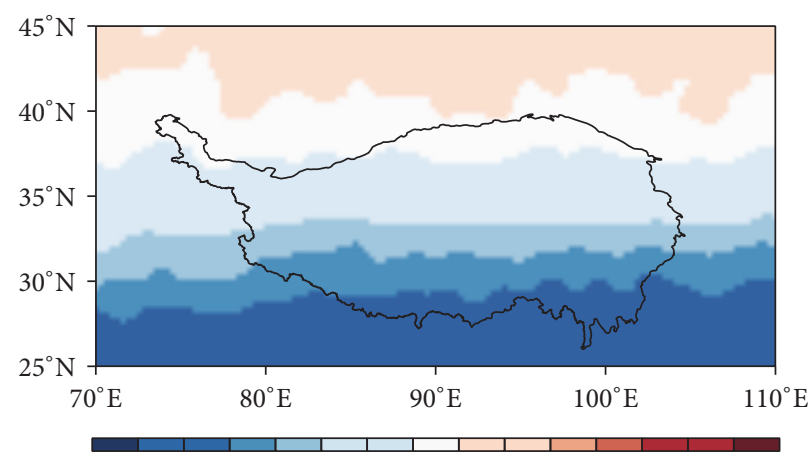

$\begin{array}{llllllllllllll}3.2 & 3.4 & 3.6 & 3.8 & 4 & 4.2 & 4.4 & 4.6 & 4.8 & 5 & 5.2 & 5.4 & 5.6 & 5.8\end{array}$

(ppmv)

(1) DJF $100 \mathrm{hPa}$

FIGURE 1: Spatial distributions of WV over the Tibetan Plateau at 215 (a-d), 147 (e-h), and 100 hPa (i-l) from MAM to DJF. Unit: ppmv.

see that WV decreases rapidly from the upper troposphere to the tropopause over the plateau and reaches a minimum value at about $80 \mathrm{hPa}$, and then, up to $10 \mathrm{hPa}, \mathrm{WV}$ increases along with height. The vertical profile of $\mathrm{WV}$ in DJF is shown in Figure 6(d). From $215 \mathrm{hPa}$ to $147 \mathrm{hPa}$, it also diminishes rapidly and then mushrooms above $147 \mathrm{hPa}$, showing a "V" structure. The vertical profiles of JJA (Figure 6(b)) and autumn (Figure 6(c)) are consistent; both of them decrease rapidly and then increase slightly. In 1978, Kley et al. [41] observed a minimum value of WV at the bottom of the tropopause in Wyoming $\left(41^{\circ} \mathrm{N}\right)$, US, and Quixeramobim $\left(5^{\circ} \mathrm{S}\right)$, Brazil. Subsequent observations also confirmed the existence of the minimum value, which was called "hygropause" by Brasseur and Solomon [42]. The minimal value occurs at around $80 \mathrm{hPa}$ in MAM (Figure 6(a)) and SON (Figure 6(c)), and it is about 4 ppmv, while the minimum values in JJA (Figure 6(b)) and DJF (Figure 6(d)) appear at $121 \mathrm{hPa}$, of which the WV in JJA is relatively larger, about 7 ppmv, and that in DJF smaller, about $3.5 \mathrm{ppmv}$.

As mentioned above, the plateau region is a heat source in summer and a cold source in winter, which leads to a great difference in the convective activity over the plateau.
Based on the analysis of monthly potential temperature over this region, Zou and Gao [43] pointed out that the strong ascending motion in summer is favorable for the transport of WV to the UTLS, while the sinking motion in winter is not conducive to such movement. Figure 7 shows the latitudeheight cross sections of the mean PV and potential temperature in different seasons. From Figures 7 (a) and 7(d), we can see that the distribution of potential temperature contours is more intensive in MAM and DJF, but relatively sparse in JJA (Figure 7(b)) and SON (Figure 7(c)). The meridional gradient of the pressure near the tropopause is the largest between $100 \mathrm{hPa}$ and $150 \mathrm{hPa}$ in MAM, and the sharp meridional gradient of tropopause pressure enhances the exchanges of air masses in both directions along the tropopause surface. The tropopause is at a lower position over the northern plateau in Figures 7 (a) and 7(d), which moves UTLS to a low altitude, and this may be one of the reasons for the higher WV content of UTLS in March and April than in other regions at the same latitude [31]. In JJA, the maximum pressure gradient near the tropopause moves out of the plateau, which is located to the north of the plateau. From the MAM and DJF figures, it can be seen that the tropopause pressure value is smaller, and the 


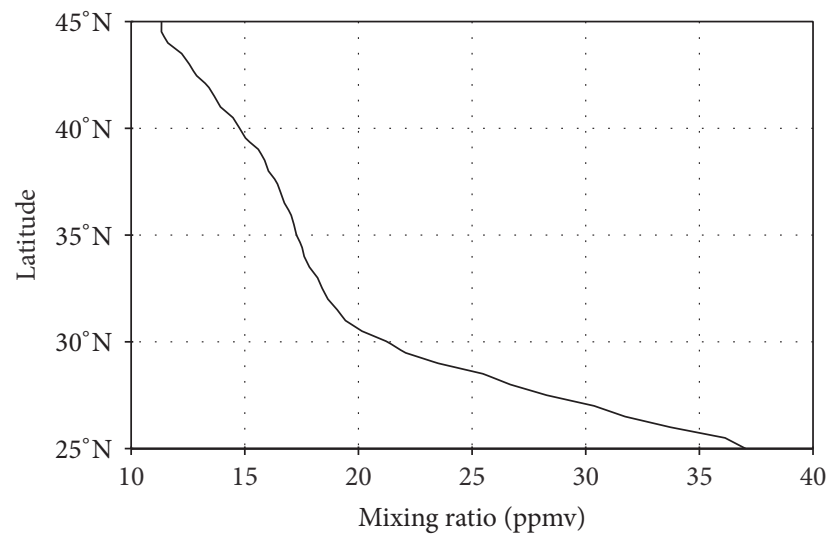

(a) MAM $215 \mathrm{hPa}$

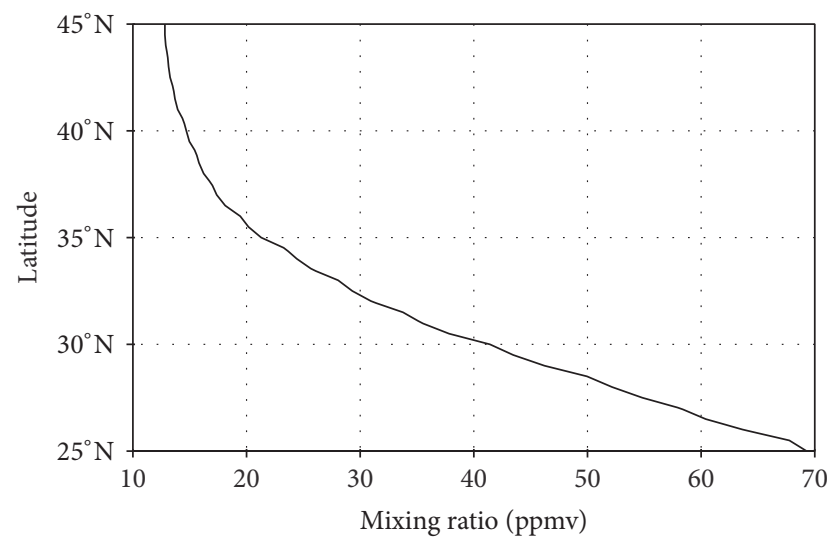

(c) $\mathrm{SON} 215 \mathrm{hPa}$

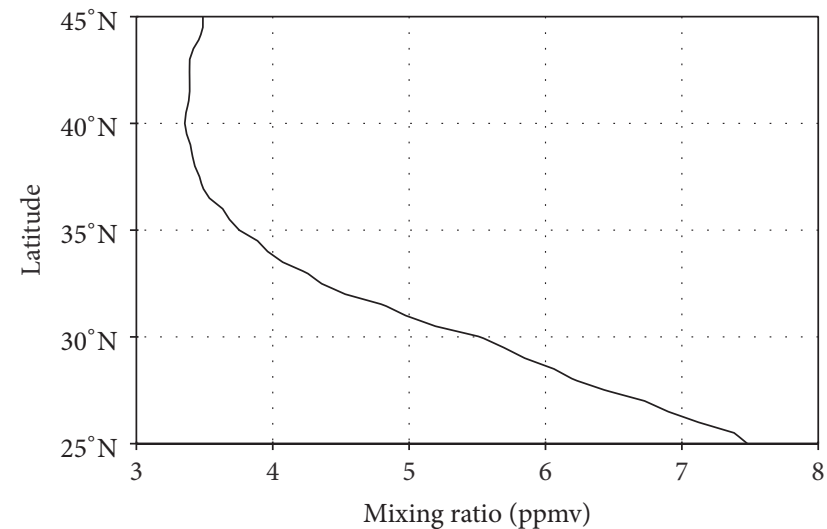

(e) $\mathrm{MAM} 147 \mathrm{hPa}$

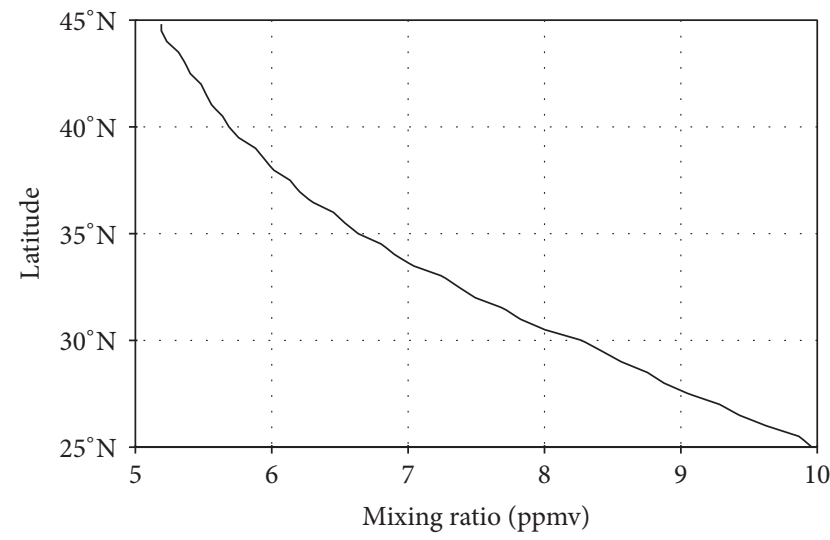

(g) $\mathrm{SON} 147 \mathrm{hPa}$

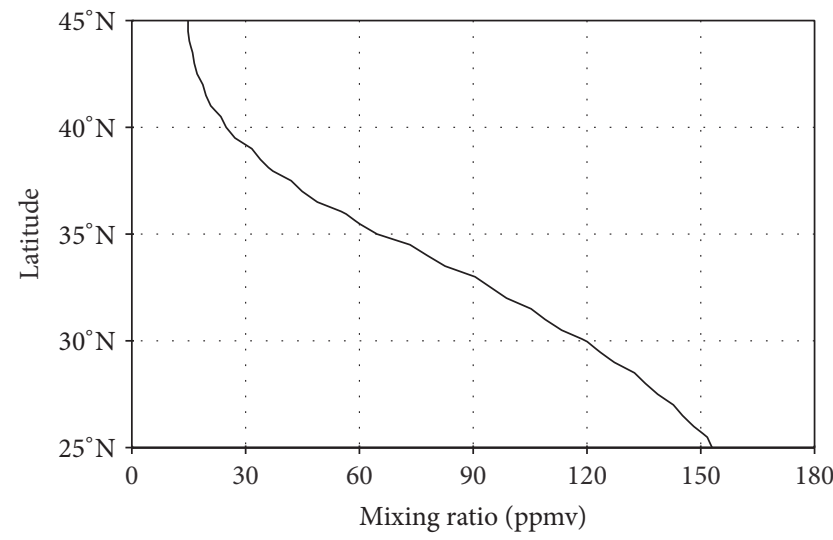

(b) JJA $215 \mathrm{hPa}$

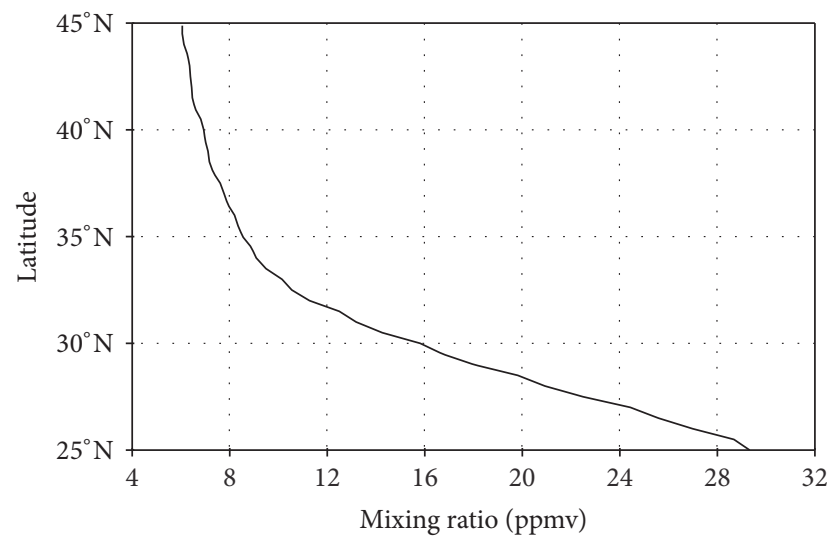

(d) DJF $215 \mathrm{hPa}$

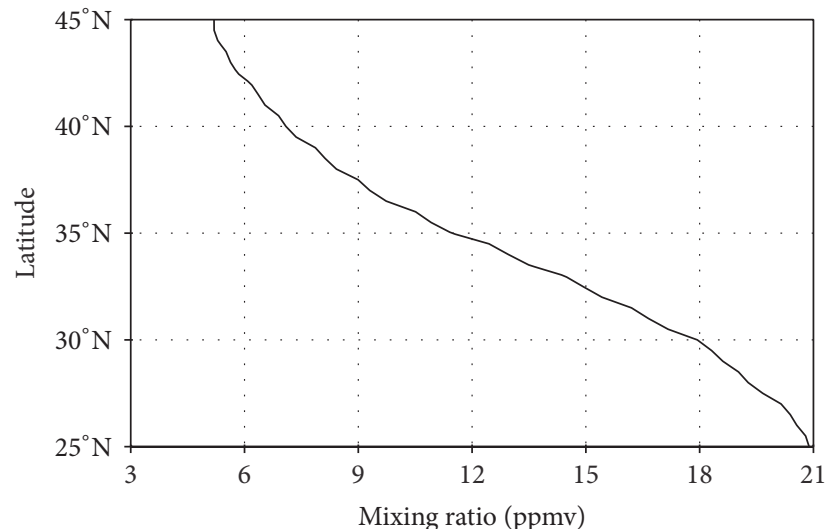

(f) JJA $147 \mathrm{hPa}$

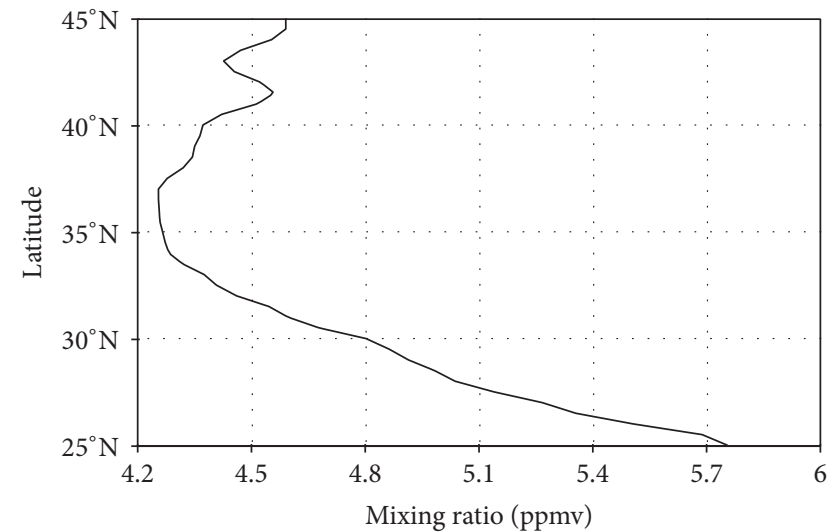

(h) DJF $147 \mathrm{hPa}$

FIgURE 2: Continued. 


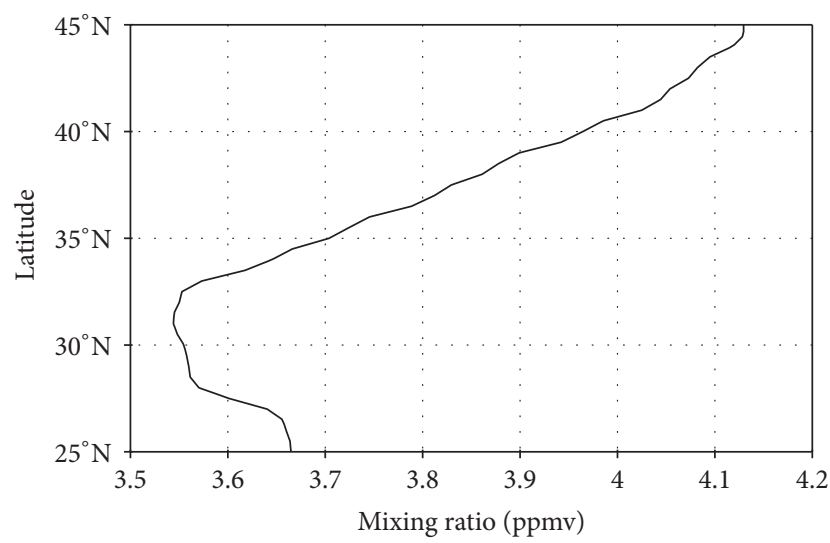

(i) MAM $100 \mathrm{hPa}$

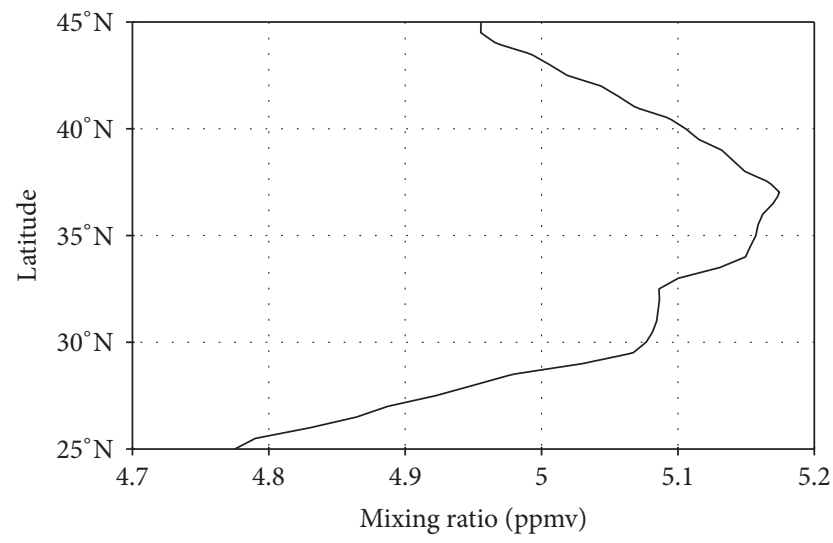

(k) SON $100 \mathrm{hPa}$

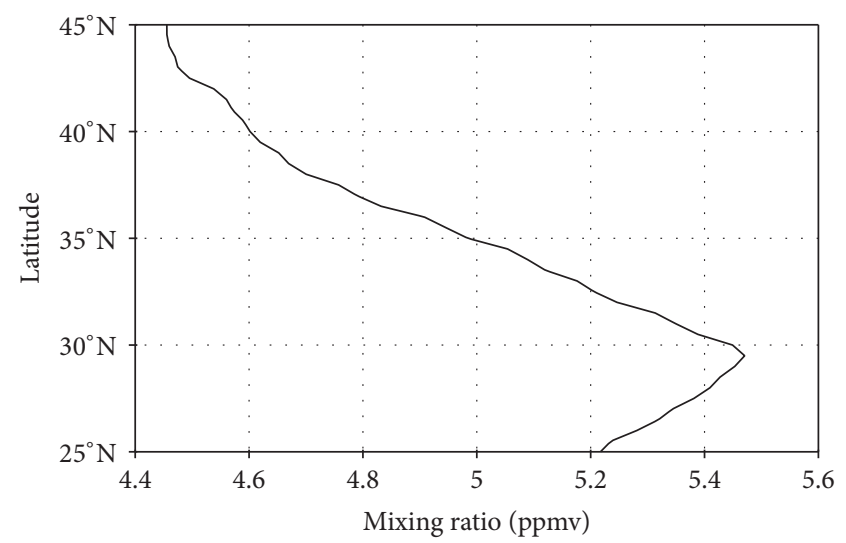

(j) JJA $100 \mathrm{hPa}$

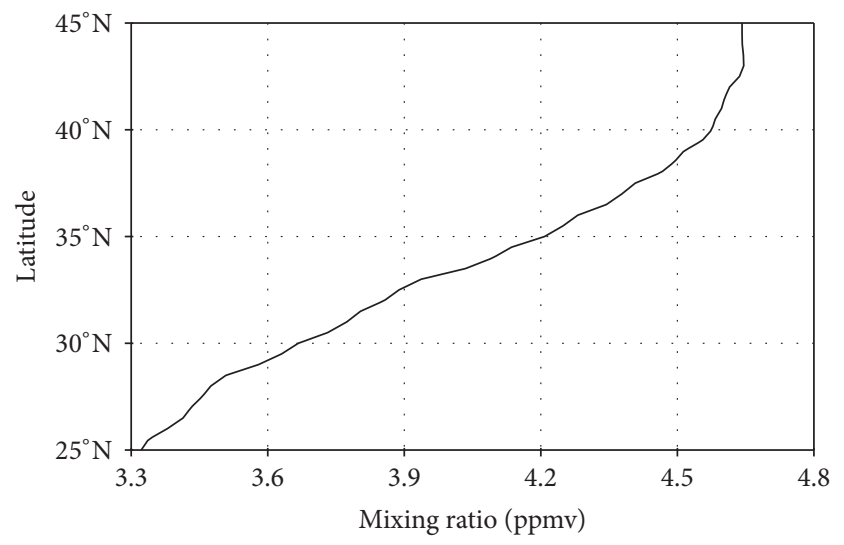

(l) DJF $100 \mathrm{hPa}$

FIGURE 2: Zonal mean distributions of WV over the Tibetan Plateau at 215 (a-d), 147 (e-h), and 100 hPa (i-l), from MAM to DJF. Unit: ppmv.

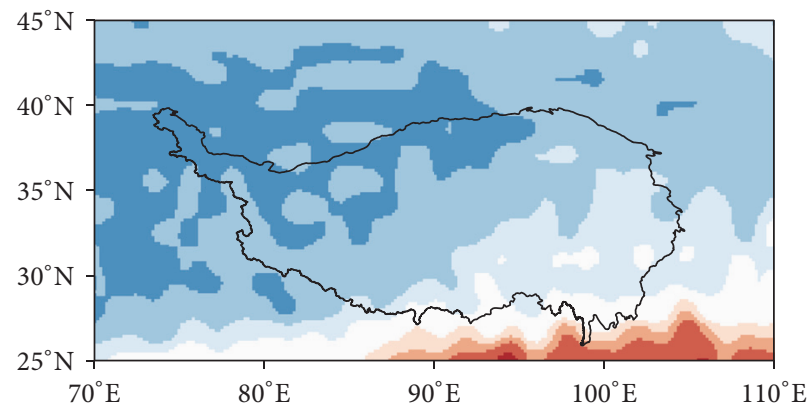

$\begin{array}{lllllllllllllll}3.2 & 3.4 & 3.6 & 3.8 & 4 & 4.2 & 4.4 & 4.6 & 4.8 & 5 & 5.2 & 5.4 & 5.6\end{array}$ (ppmv)

(a) MAM

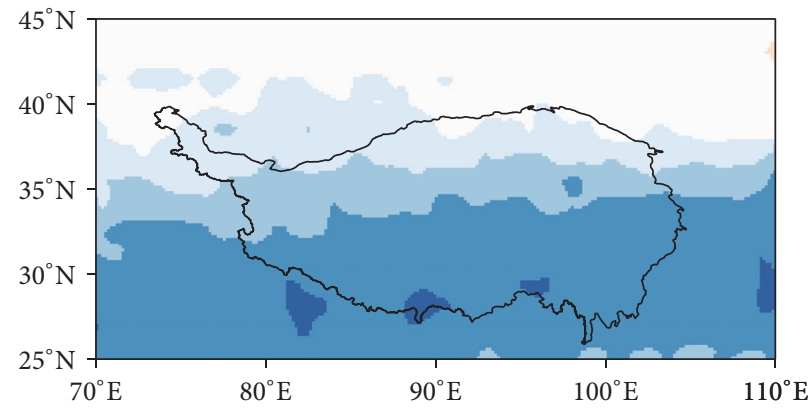

$\begin{array}{llllllllllllll}3.2 & 3.4 & 3.6 & 3.8 & 4 & 4.2 & 4.4 & 4.6 & 4.8 & 5 & 5.2 & 5.4 & 5.6\end{array}$ (ppmv)

(b) DJF

FIgure 3: Same as Figure 1, but only for MAM (a) and DJF (b) at $121 \mathrm{hPa}$.

distributions of PV contours indicate sinking trends in the upper troposphere over the plateau. The rapid development of strong convective movements in summer causes the sinking trends over the plateau to disappear.
3.3. Variation Trends of Water Vapor. Since the motion trends of gases, including WV, vary by height and region [43], we analyzed the variation trends of $\mathrm{WV}$ at different pressure levels. Figure 8 shows the variation trends of WVMR at 100, 


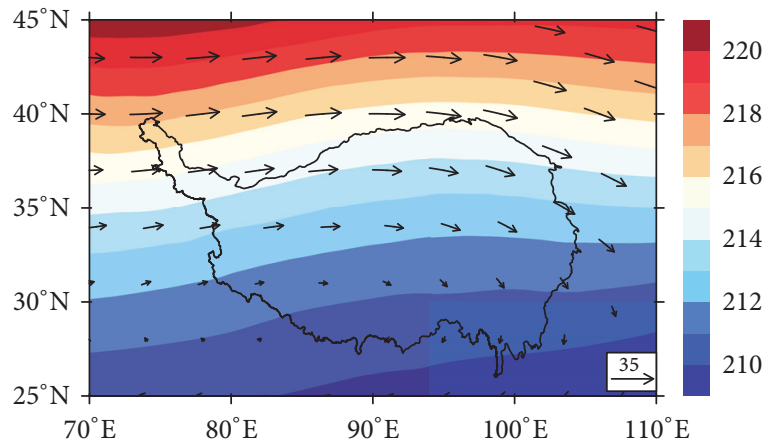

(a) JJA $150 \mathrm{hPa}$

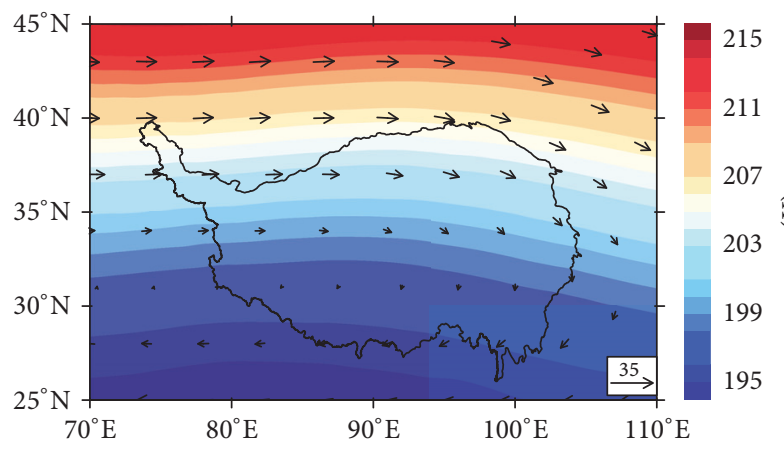

(c) JJA $100 \mathrm{hPa}$

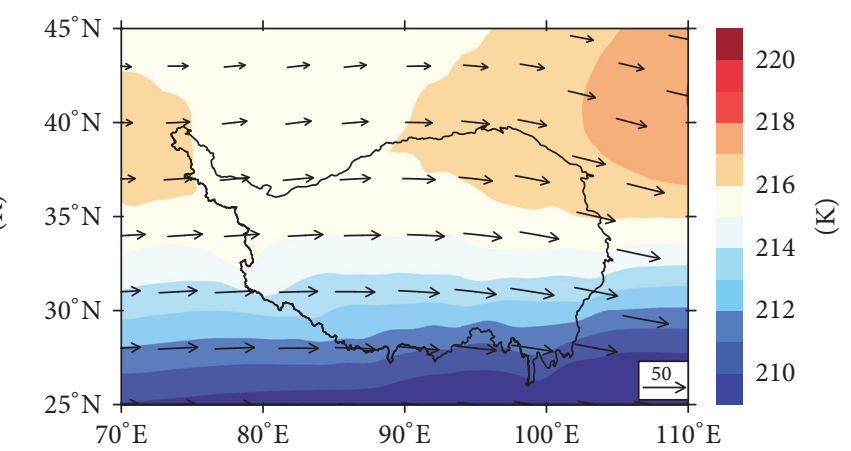

(b) DJF $150 \mathrm{hPa}$

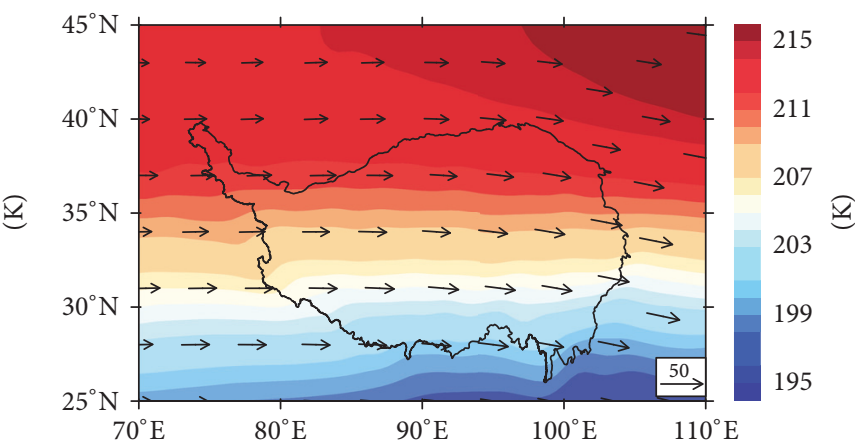

(d) DJF $100 \mathrm{hPa}$

FIgURE 4: Spatial distributions of wind and temperature at 150 and $100 \mathrm{hPa}$; (a, c) JJA; (b, d) DJF.

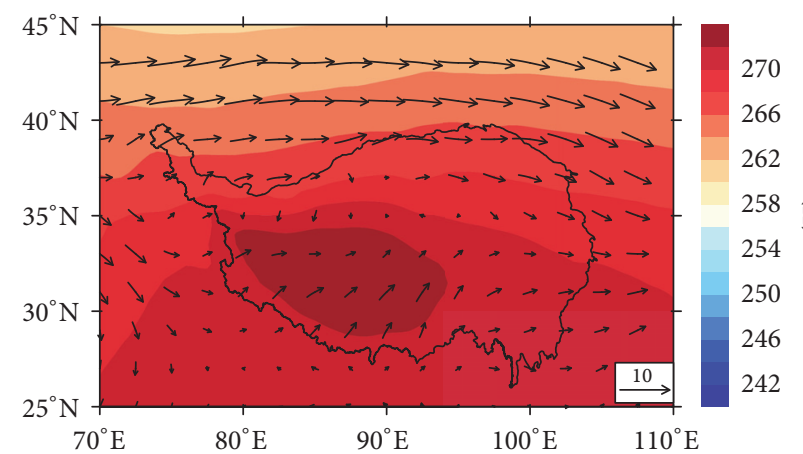

(a) JJA $500 \mathrm{hPa}$

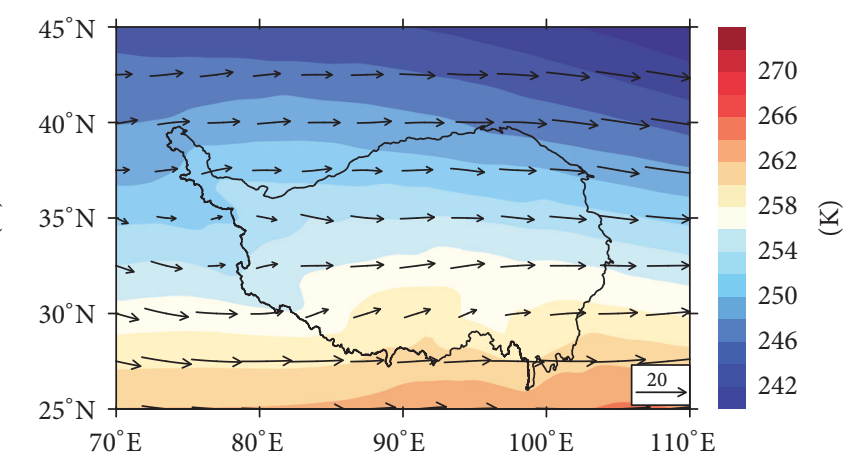

(b) DJF $500 \mathrm{hPa}$

FIGURE 5: Same as Figure 4, but for $500 \mathrm{hPa}$.

147 , and $215 \mathrm{hPa}$ over the plateau $\left(28^{\circ} \mathrm{N}-40^{\circ} \mathrm{N}, 75^{\circ} \mathrm{E}-105^{\circ} \mathrm{E}\right)$ from 2005 to 2016 . As can be seen from the moving average curve in Figure 8, in addition to the seasonal changes, there is significant interannual change. Over the past 12 years, WV has shown a weak rising trend with an annual increase of $0.148 \%$ at $100 \mathrm{hPa}$ (Figure $8(\mathrm{a})$ ), although this change tendency was not prominent before 2012. At both $147 \mathrm{hPa}$ (Figure 8(b)) and $215 \mathrm{hPa}$ (Figure 8(c)), WV shows weak downward trends. Although the interannual variations in the two heights are not obvious compared with that at $100 \mathrm{hPa}$, both of them still show the periods of quasi-3-year oscillation according to the moving average curves. It has been pointed out that the variation trends of water vapor and methane in the stratosphere have been opposite over the plateau, because the oxidation of methane generates more WV $[44,45]$.

Figure 9 shows the variation of $\mathrm{WV}$ at diverse altitudes over the plateau throughout the four seasons. The $\mathrm{WV}$ content in JJA is close to that in autumn at $100 \mathrm{hPa}$ (Figure 9(a)). DJF has more WV than MAM, but they both show similar variation tendencies at the pressure layer of 


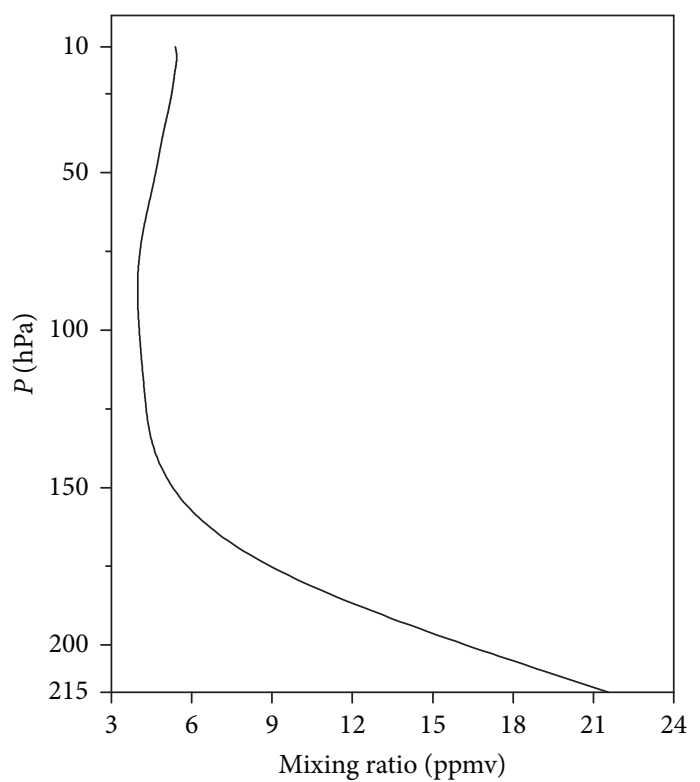

(a) MAM

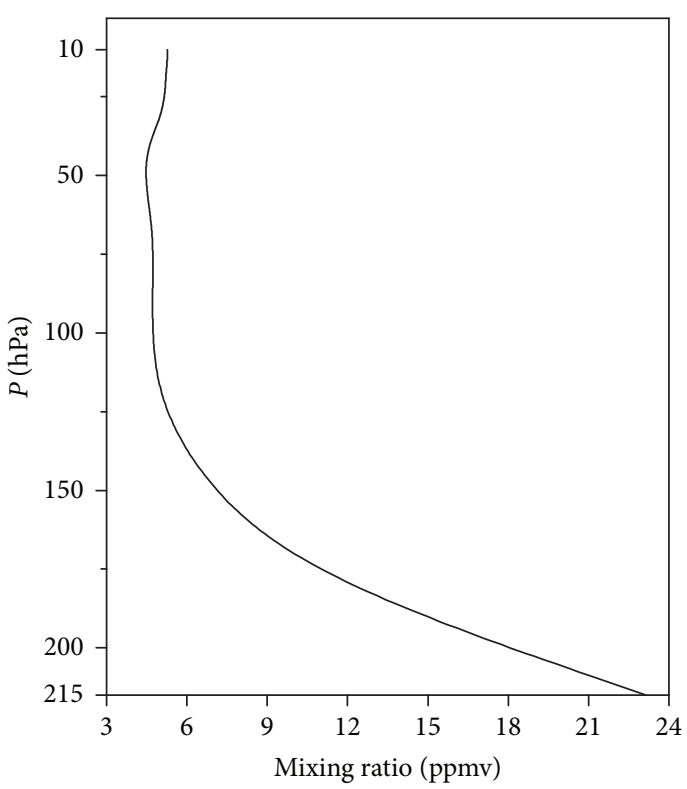

(c) SON

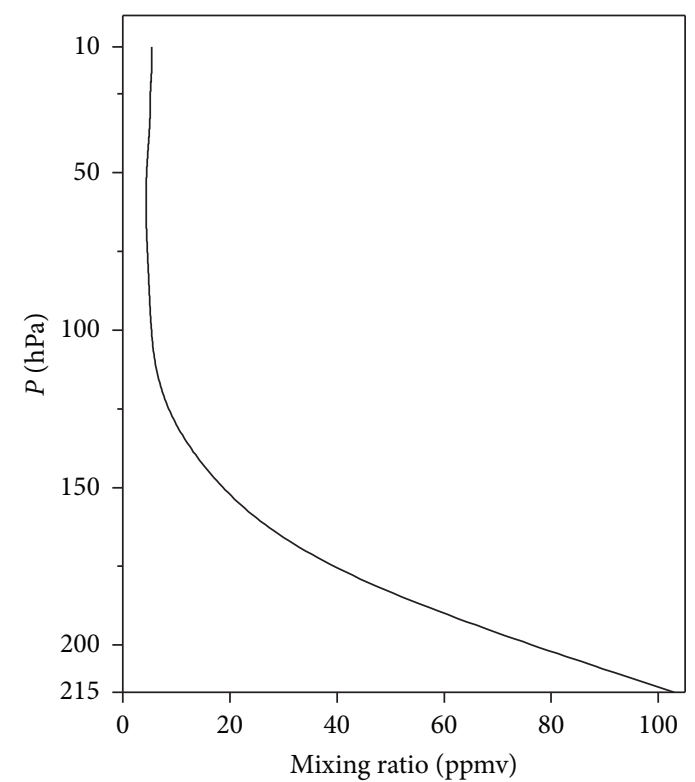

(b) JJA

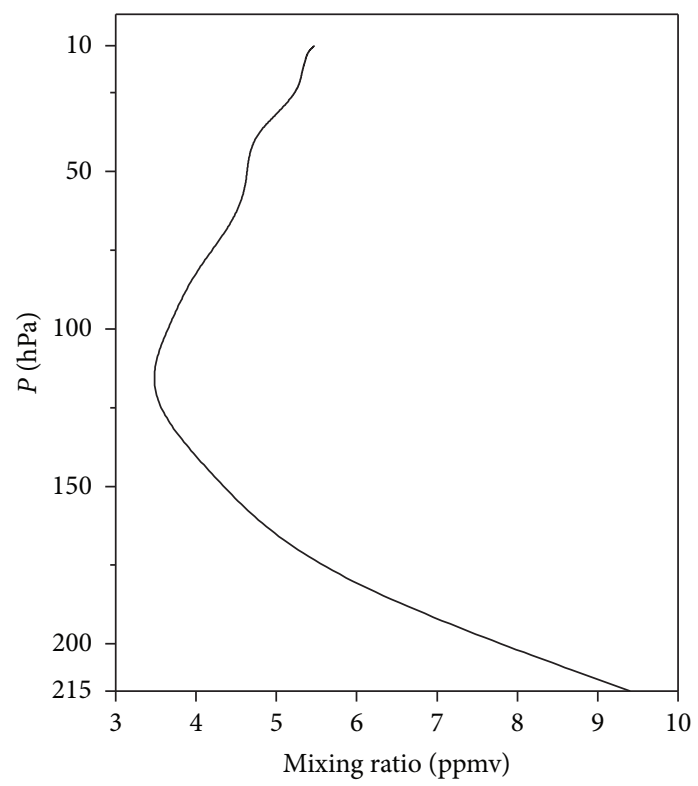

(d) DJF

FIgURE 6: Vertical profiles of WV over the Tibetan Plateau $\left(28^{\circ} \mathrm{N}-40^{\circ} \mathrm{N}, 75^{\circ} \mathrm{E}-105^{\circ} \mathrm{E}\right)$. Unit: ppmv.

$100 \mathrm{hPa}$ (Figure 9(a)). Both of the WV in DJF and MAM show an increasing trend with trend ratios reaching $0.171 \mathrm{ppmv} / 10 \mathrm{a}$ and $0.071 \mathrm{ppmv} / 10 \mathrm{a}$. At the $147 \mathrm{hPa}$ (Figure 9(b)) and $215 \mathrm{hPa}$ (Figure 9(c)) heights, the WV in JJA is much greater than in other seasons. In SON it is less, and then the minimum is found during DJF at $215 \mathrm{hPa}$. Figure 9(b) indicates that the $\mathrm{WV}$ values in spring and winter are very similar, but there is no evident fluctuation. It is clear that the $\mathrm{WV}$ content is lowest in winter (from Figure 9(c)) and that the variations of $\mathrm{WV}$ show a rough wave structure in MAM and SON at the $215 \mathrm{hPa}$ height.

\section{Conclusions}

In this study, AURA/MLS observation data and ERA-Interim meteorological data were used to analyze the characteristics of WV in the UTLS over the Tibetan Plateau from 2005 to 2016, including horizontal and vertical distributions, and temporal variation. The analysis results show that a high WV content is more apparent in the UTLS over the southern portion of the Tibetan Plateau than in the northern area of the plateau in JJA, due to the monsoon-induced strong upward motions. During the winter and spring seasons, the 


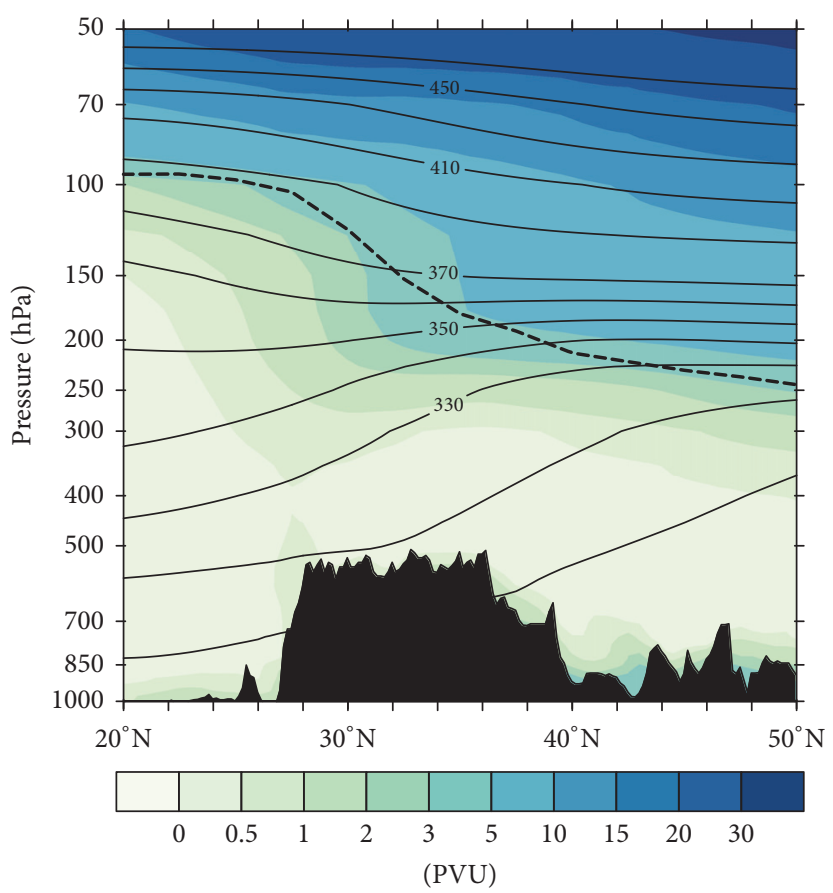

(a) MAM

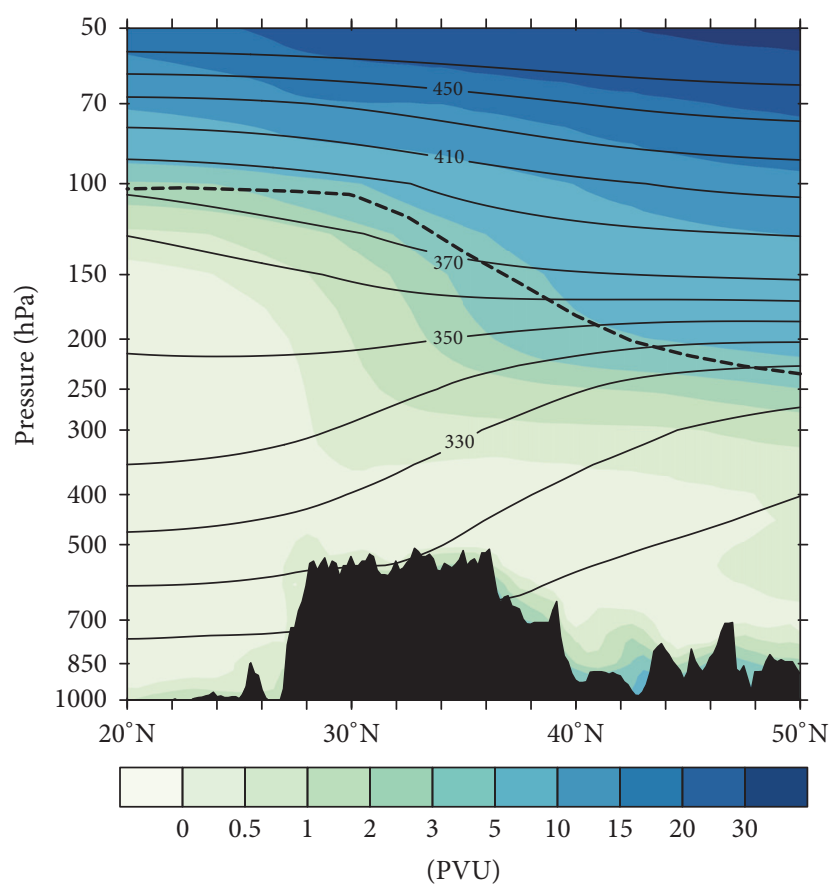

(c) $\mathrm{SON}$

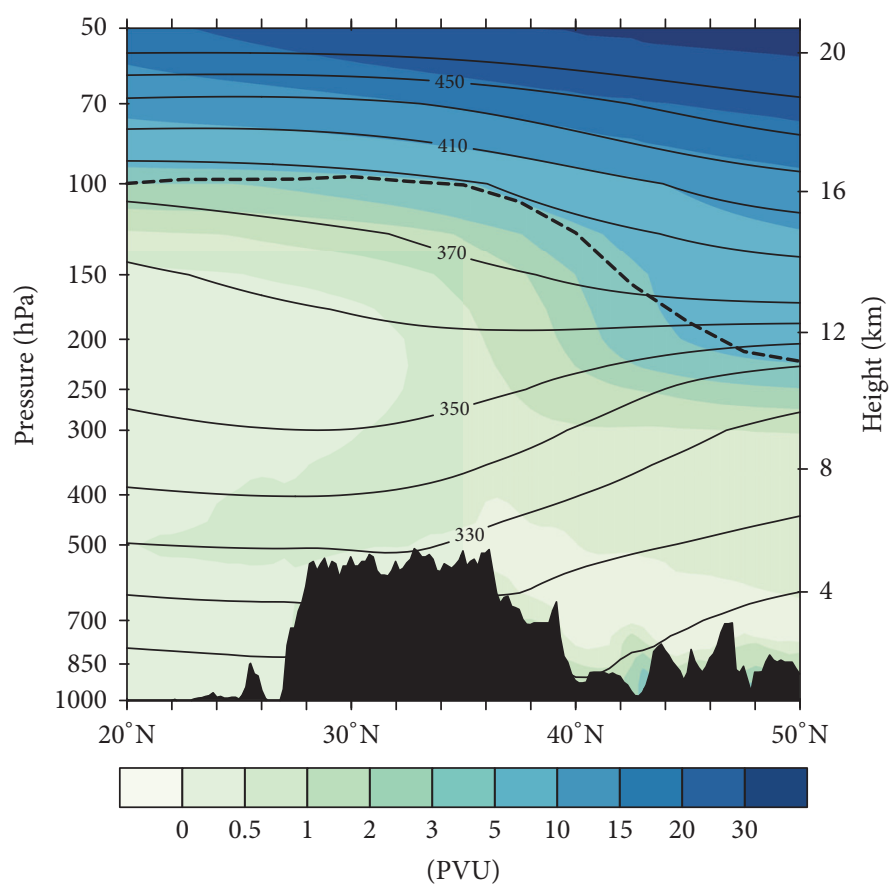

(b) JJA

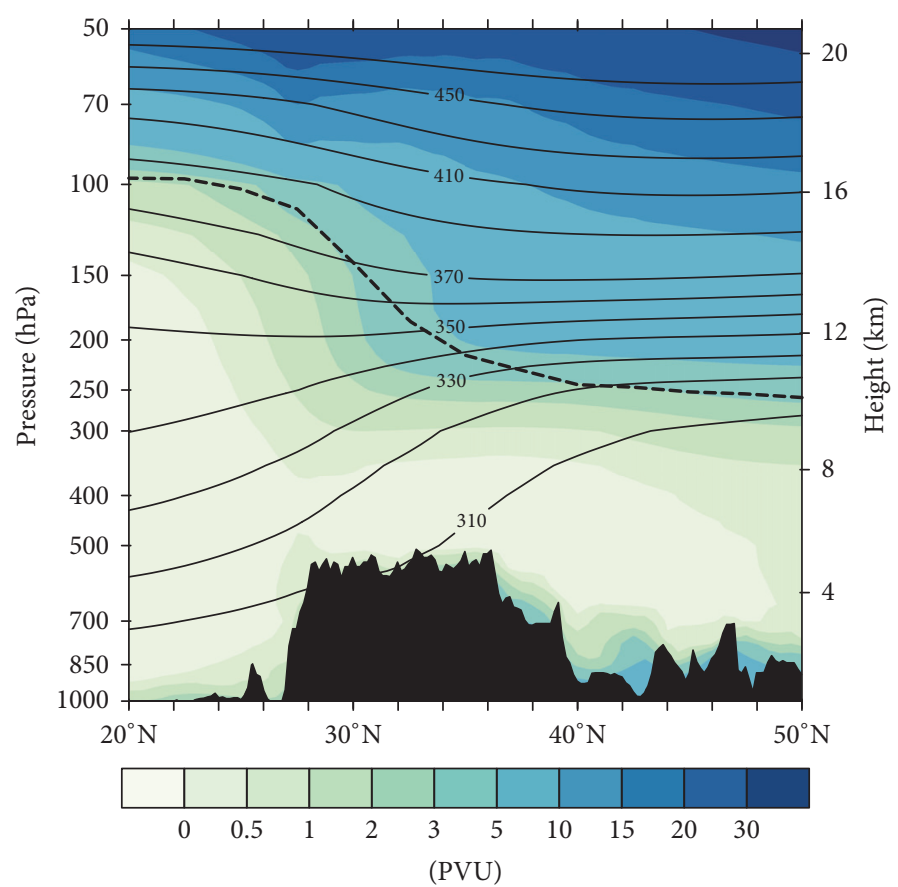

(d) DJF

Figure 7: Latitude-height (averaged over the longitude $75^{\circ} \mathrm{E}-105^{\circ} \mathrm{E}$ ) cross sections of the mean PV fields (color contours) and potential temperature (thin lines). The thick dashed lines represent the tropopause. $1 \mathrm{PVU}=1.0 E^{-6} \mathrm{~m}^{2} \mathrm{~s}^{-1} \mathrm{~K} \mathrm{~kg}^{-1}$. The potential temperature unit is K.

distribution differences between the north and south in the lower stratosphere showed opposite trends. In MAM, the WV in the UTLS diminished rapidly with an increase of altitude and was similar to that in DJF, which shows a "V" structure.
The lower position of the UTLS may lead to a higher WV content over the northern Tibetan Plateau than in ambient regions of the same latitude. The temporal variations of $\mathrm{WV}$ show a weak increasing trend at $100 \mathrm{hPa}$ over the past 12 years, 


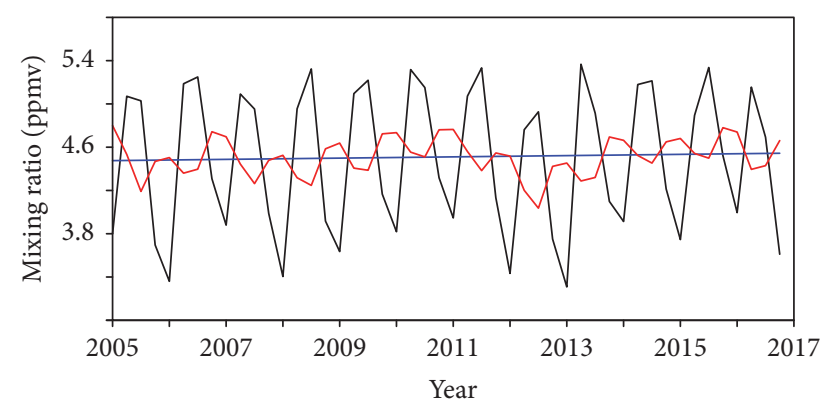

(a) $100 \mathrm{hPa}$

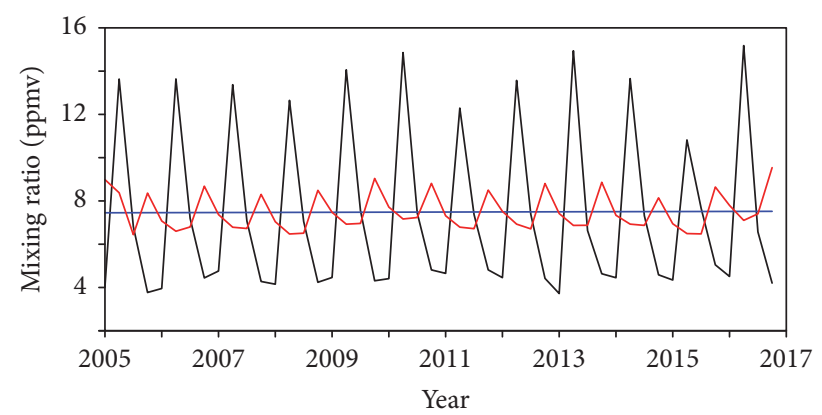

(b) $147 \mathrm{hPa}$

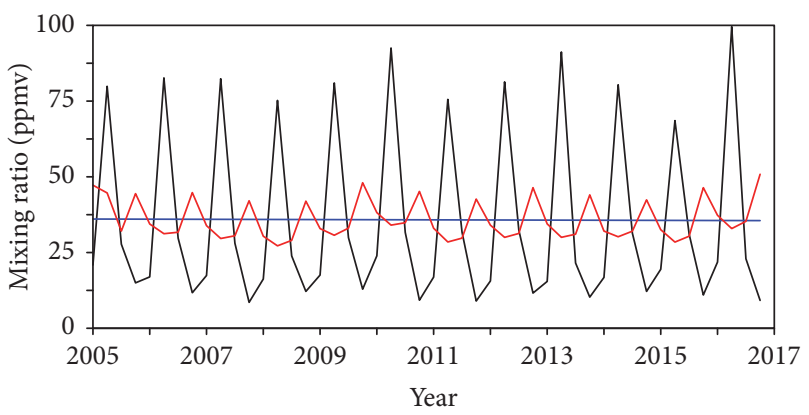

(c) $215 \mathrm{hPa}$

FIGURE 8: Temporal variation of WV at 100 (a), 147 (b), and $215 \mathrm{hPa}$ (c) over the Tibetan Plateau. Black lines represent primary data, red lines the moving averages, and blue lines the linear trends. Unit: ppmv.

while trends in MAM and DJF remained essentially constant. Downtrends occurred at 147 and $215 \mathrm{hPa}$, and the WV in summer is much greater than in other seasons, with autumn next, then the minimum in winter. Moreover, WV shows a rough wave structure in MAM and SON at $215 \mathrm{hPa}$.

When the refined structure of WV near the tropopause was analyzed in this study, only a few pressure levels-those detected by the MLS instrument-could be obtained. More detailed structural transformations are still not clear. For instance, at what pressure level do the distributions of WV over the northern and southern plateau begin to turn around? And what are the mechanisms of this transformation? Further research will have to rely on numerical modeling to a considerable degree.

\section{Conflicts of Interest}

The authors declare that there are no conflicts of interest.

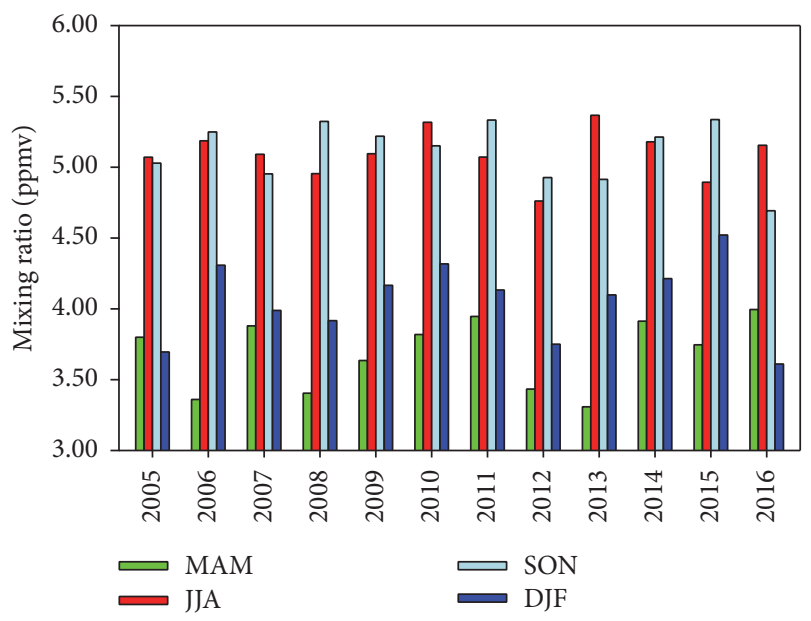

(a) $100 \mathrm{hPa}$

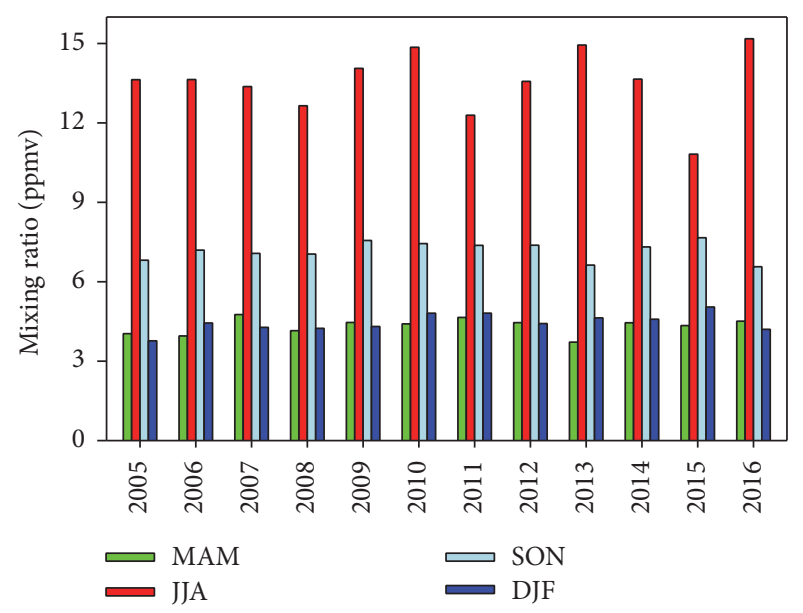

(b) $147 \mathrm{hPa}$

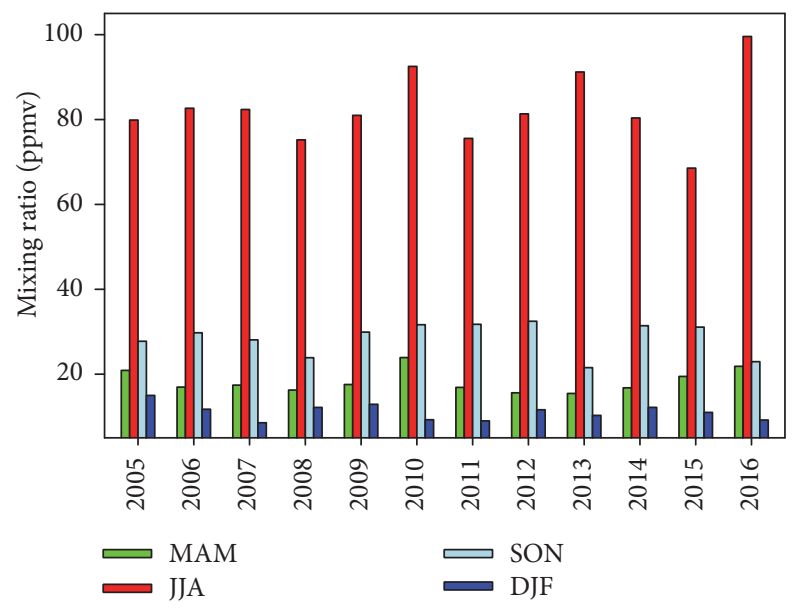

(c) $215 \mathrm{hPa}$

FIGURE 9: Same as Figure 8, but with seasonal variations.

\section{Acknowledgments}

This work was supported by the National Science Foundation of China (41475037). The authors acknowledge the datasets from the AURA/MLS and ERA-Interim. 


\section{References}

[1] A. Sinha and J. E. Harries, "Water vapour and greenhouse trapping: The role of far infrared absorption," Geophysical Research Letters, vol. 22, no. 16, pp. 2147-2150, 1995.

[2] I. M. Held and B. J. Soden, "Water vapor feedback and global warming," Annual Review of Energy and the Environment, vol. 25, pp. 441-475, 2000.

[3] F. Forster, M. Piers, and K. P. Shine, "Stratospheric water vapour changes as a possible contributor to observed stratospheric cooling," Geophysical Research Letters, vol. 26, no. 21, pp. 33093312, 1999.

[4] S. J. Oltmans and D. J. Hofmann, "Increase in lowerstratospheric water vapour at a mid-latitude Northern Hemisphere site from 1981 to 1994," Nature, vol. 374, no. 6518, pp. 146149, 1995.

[5] S. Kremser, M. Rex, U. Langematz, M. Dameris, and I. Wohltmann, "Validation of water vapour transport in the tropical tropopause region in coupled Chemistry Climate Models," Atmospheric Chemistry and Physics Discussions, vol. 8, no. 3, pp. 10999-11037, 2008.

[6] P. W. Mote, K. H. Rosenlof, M. E. McIntyre et al., "An atmospheric tape recorder: the imprint of tropical tropopause temperatures on stratospheric water vapor," Journal of Geophysical Research, vol. 101, no. D2, pp. 3989-4006, 1996.

[7] C. H. Shi, B. Zheng, and Y. J. Chen, "The quasi-biennial oscillation of water vapor in tropic stratosphere," Chinese Journal of Geophysics, vol. 52, no. 10, pp. 2428-2435, 2009 (Chinese).

[8] C.-H. Shi, H. Li, B. Zheng, and D. Guo, "An atypical cold vortex structure and its precipitation over Northeast China based on Cloudsat detection," Chinese Journal of Geophysics, vol. 56, no. 8, pp. 2594-2602, 2013 (Chinese).

[9] C. H. Shi, H. Li, B. Zheng et al., "Stratosphere-troposphere exchange corresponding to a deep convection in warm sector and abnormal subtropical front induced by a cutoff low over east asia," Chinese Journal of Geophysics, vol. 57, no. 1, pp. 21-30, 2014 (Chinese).

[10] A. Raval and V. Ramanathan, "Observational determination of the greenhouse effect," Nature, vol. 342, no. 6251, pp. 758-761, 1989.

[11] R. D. Cess, G. L. Potter, J. P. Blanchet et al., "Intercomparison and interpretation of climate feedback processes in 19 atmospheric general circulation models," Journal of Geophysical Research Atmospheres, vol. 95, no. D10, pp. 16601-16615, 1990.

[12] B. J. Soden, D. L. Jackson, V. Ramaswamy, M. D. Schwarzkopf, and X. Huang, "The radiative signature of upper tropospheric moistening," Science, vol. 310, no. 5749, pp. 841-844, 2005.

[13] S. Solomon, K. H. Rosenlof, R. W. Portmann et al., "Contributions of stratospheric water vapor to decadal changes in the rate of global warming," Science, vol. 327, no. 5970, pp. 1219-1223, 2010.

[14] R. S. Lindzen, "Some coolness concerning global warming," Bulletin of the American Meteorological Society, vol. 71, no. 3, pp. 288-299, 1990.

[15] D. Z. Sun and R. S. Lindzen, "Distribution of tropical tropospheric water vapor," Journal of the Atmospheric Sciences, vol. 50, no. 12, pp. 1643-1660, 1993.

[16] R. S. Lindzen, M.-D. Chou, and A. Y. Hou, "Does the earth have an adaptive infrared iris?" Bulletin of the American Meteorological Society, vol. 82, no. 3, pp. 417-432, 2001.

[17] X. J. Zhou, C. Luo, and W. L. Li, "The column ozone variation in China and the the low value ozone center over Tibetan Plateau,"
Chinese Science Bulletin, vol. 40, no. 15, pp. 1396-1398, 1995 (Chinese).

[18] A. Gettelman, D. E. Kinnison, T. J. Dunkerton, and G. P. Brasseur, "Impact of monsoon circulations on the upper troposphere and lower stratosphere," Journal of Geophysical Research D: Atmospheres, vol. 109, no. 22, pp. 51-67, 2004.

[19] W. J. Randel, M. Park, L. Emmons et al., "Asian monsoon transport of pollution to the stratosphere," Science, vol. 328, no. 5978, pp. 611-613, 2010.

[20] W. J. Randel and M. Park, "Deep convective influence on the Asian summer monsoon anticyclone and associated tracer variability observed with Atmospheric Infrared Sounder (AIRS)," Journal of Geophysical Research Atmospheres, vol. 111, no. D12, Article ID D12314, 2006.

[21] D. R. Jackson, S. J. Driscoll, E. J. Highwood, J. E. Harries, and J. M. Russell, "Troposphere to stratosphere transport at low latitudes as studied using HALOE observations of water vapour 1992-1997," Quarterly Journal of the Royal Meteorological Society, vol. 124, no. 545, pp. 169-192, 1998.

[22] R. Fu, Y. Hu, J. S. Wright et al., "Short circuit of water vapor and polluted air to the global stratosphere by convective transport over the Tibetan Plateau," Proceedings of the National Academy of Sciences of the United States of America, vol. 103, no. 15, pp. 5664-5669, 2006.

[23] S. J. Evans, R. Toumi, J. E. Harries, M. R. Chipperfield, and J. M. Russell, "Trends in stratospheric humidity and the sensitivity of ozone to these trends," Journal of Geophysical Research: Atmospheres, vol. 103, no. D8, pp. 8715-8725, 1998.

[24] C. A. Smith, R. Toumi, and J. D. Haigh, "Seasonal trends in stratospheric water vapour," Geophysical Research Letters, vol. 27, no. 12, pp. 1687-1690, 2000.

[25] H. L. Clark, R. S. Harwood, P. W. Mote et al., "Variability of water vapor in the tropical upper troposphere as measured by the Microwave Limb Sounder on UARS," Journal of Geophysical Research: Atmospheres, vol. 103, no. D24, pp. 31695-31707, 1998.

[26] P. W. Mote, H. L. Clark, T. J. Dunkerton et al., "Intraseasonal variations of water vapor in the tropical upper troposphere and tropopause region," Journal of Geophysical Research Atmospheres, vol. 105, no. D13, pp. 17454-17470, 2000.

[27] N. Eguchi and M. Shiotani, "Intraseasonal variations of water vapor and cirrus clouds in the tropical upper troposphere," Journal of Geophysical Research D: Atmospheres, vol. 109, no. D12, Article ID D12106, 2004.

[28] A. E. Dessler, M. R. Schoeberl, T. Wang, S. M. Davis, K. H. Rosenlof, and J.-P. Vernier, "Variations of stratospheric water vapor over the past three decades," Journal of Geophysical Research: Atmospheres, vol. 119, no. 22, pp. 12588-12598, 2014.

[29] S. Sridharan and M. Sandhya, "Long-term (2004-2015) tendencies and variabilities of tropical UTLS water vapor mixing ratio and temperature observed by AURA/MLS using multivariate regression analysis," Journal of Atmospheric and Solar-Terrestrial Physics, vol. 147, pp. 156-165, 2016.

[30] K. N. Uma, S. K. Das, and S. S. Das, "A climatological perspective of water vapor at the UTLS region over different global monsoon regions: Observations inferred from the AuraMLS and reanalysis data," Climate Dynamics, vol. 43, no. 1-2, pp. 407-420, 2014.

[31] W. Tian, H. Tian, S. Dhomse, and W. Feng, "A study of upper troposphere and lower stratosphere water vapor above the Tibetan Plateau using AIRS and MLS data," Atmospheric Science Letters, vol. 12, no. 2, pp. 233-239, 2011. 
[32] B. T. Kuwagata, A. Numaguti, and N. Endo, "Diurnal variation of water vapor over the central Tibetan plateau during summer," Journal of the Meteorological Society of Japan, vol. 79, no. 1, pp. 401-418, 2001.

[33] J. C. Bian, R. C. Yan, and H. B. Chen, "Tropospheric pollutant transport to the stratosphere by Asian summer monsoon," Chinese Journal of Atmospheric Sciences, vol. 35, no. 5, pp. 897902, 2011 (Chinese).

[34] B. Chen, X.-D. Xu, S. Yang, and H.-C. Bian, "On the characteristics of water vapor transport from atmosphere boundary layer to stratosphere over Tibetan Plateau regions in summer," Chinese Journal of Geophysics, vol. 55, no. 2, pp. 406-414, 2012 (Chinese).

[35] D. F. Hurst, A. Lambert, W. G. Read et al., "Validation of Aura Microwave Limb Sounder stratospheric water vapor measurements by the NOAA frost point hygrometer," Journal of Geophysical Research: Atmospheres, vol. 119, no. 3, pp. 1612-1625, 2014.

[36] N. J. Livesey, W. G. Read, L. Froidevaux et al., "Version 3.3 Level 2 data quality and description document," Tech. Rep. D-335.9, Jet Propulsion Laboratory, 2011.

[37] A. Lambert, W. G. Read, N. J. Livesey et al., "Validation of the Aura Microwave Limb Sounder middleatmosphere water vapor and nitrous oxide measurements," Journal of Geophysical Research: Atmosphere, vol. 112, no. D24, Article ID D24S36, 2007.

[38] M. J. Schwartz, A. Lambert, and G. L. Manney, "Validation of the Aura Microwave Limb Sounder temperature and geopotential height measurements," Journal of Geophysical Research: Atmospheres, vol. 113, no. D15, Article ID D15S11, 2008.

[39] B. Chen, X. H. Shi, X. D. Xu et al., "Characteristics of UT/LS carbon monoxide interseasonal oscillations and their associated factors over the Tibetan Plateau and its adjacent areas in summer," Journal of Tropical Meteorology, vol. 27, no. 5, pp. 679689, 2011 (Chinese).

[40] B. Chen and X. Liu, "Seasonal migration of circus clouds over the Asian Monsoon regions and the Tibetan Plateau measured from MODIS/Terra," Geophysical Research Letters, vol. 32, no. 1, pp. 1-4, 2005.

[41] D. Kley, E. J. Stone, W. R. Henderson et al., "In situ measurements of the mixing ratio of water vapor in the stratosphere," Journal of the Atmospheric Sciences, vol. 36, no. 12, pp. 25132524, 1979.

[42] G. Brasseur and S. Solomon, Aeronomy of the Middle Stratosphere: Chemistry and Physics of the Stratosphere and Mesosphere, Springer, 1986.

[43] H. Zou and Y. Gao, "Vertical ozone profile over Tibet using SAGE I and II data," Advances in Atmospheric Sciences, vol. 14, no. 4, pp. 505-512, 1997.

[44] Y. Chen, R. Zhou, C. Shi, and Y. Bi, "Study on the trace species in the stratosphere and their impact on climate," Advances in Atmospheric Sciences, vol. 23, no. 6, pp. 1020-1039, 2006.

[45] Y. Bi, Y. J. Chen, R. J. Zhou et al., "Study on $\mathrm{H}_{2} \mathrm{O}$ and $\mathrm{CH}_{4}$ distributions and variations over Qinghai-Xizang plateau using HALOE data," Plateau Meteorology, vol. 27, no. 2, pp. 249-258, 2008 (Chinese). 

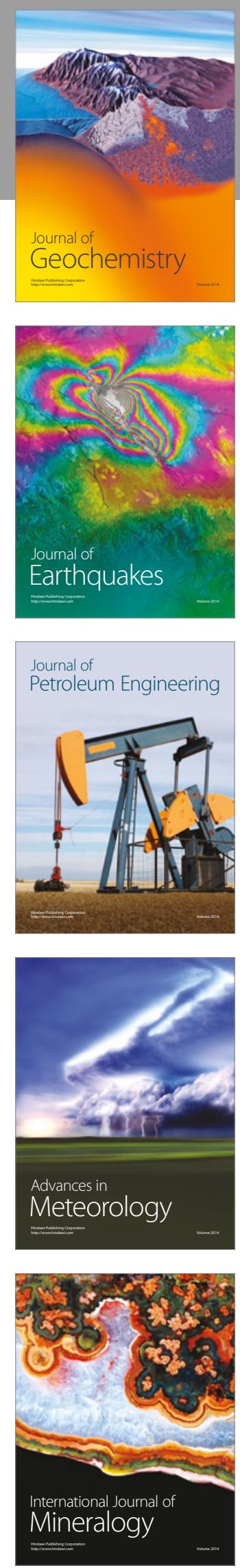
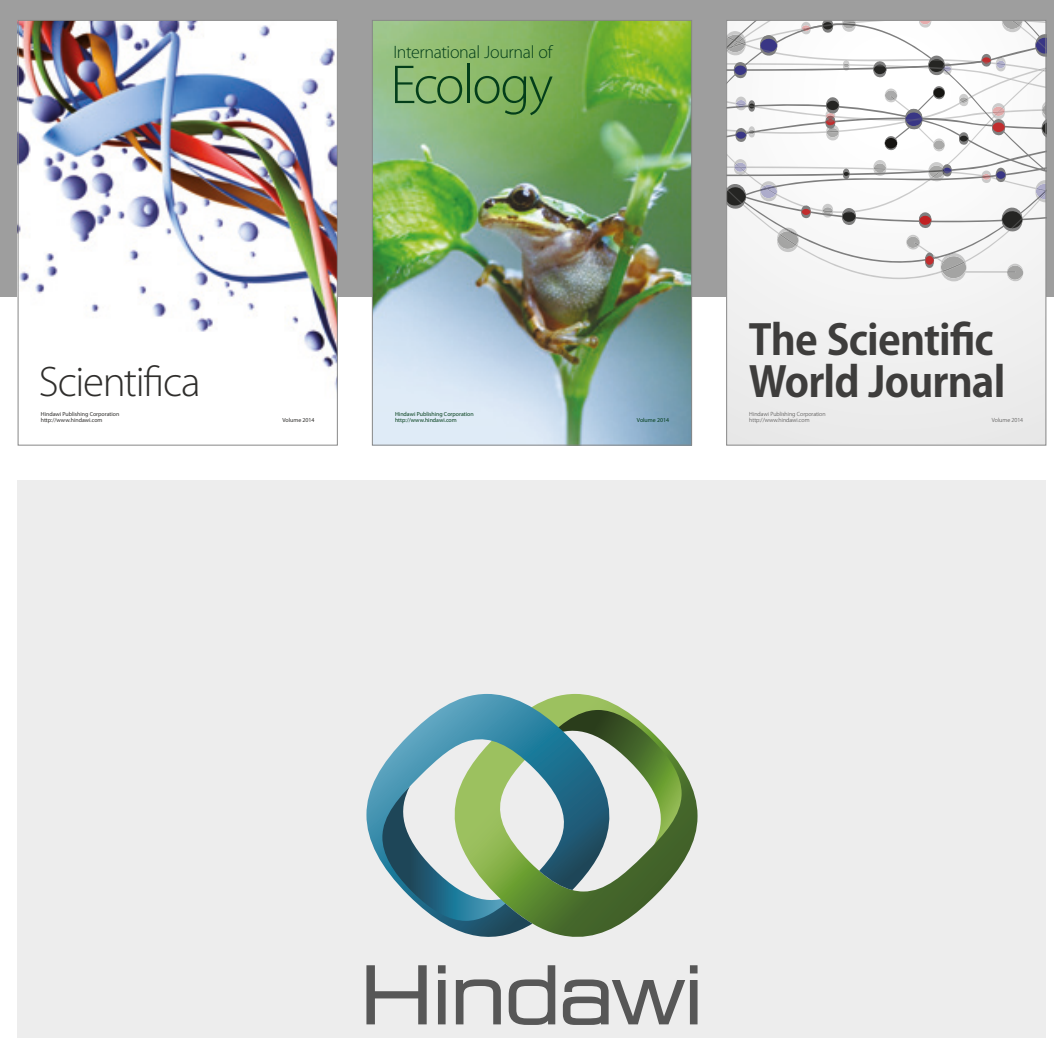

Submit your manuscripts at

https://www.hindawi.com
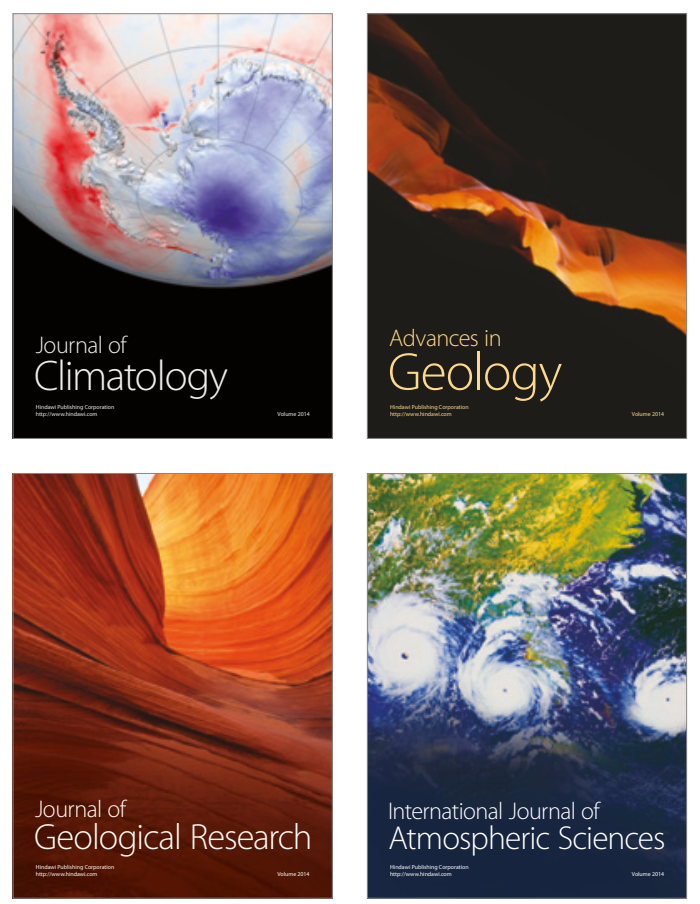

The Scientific

World Journal
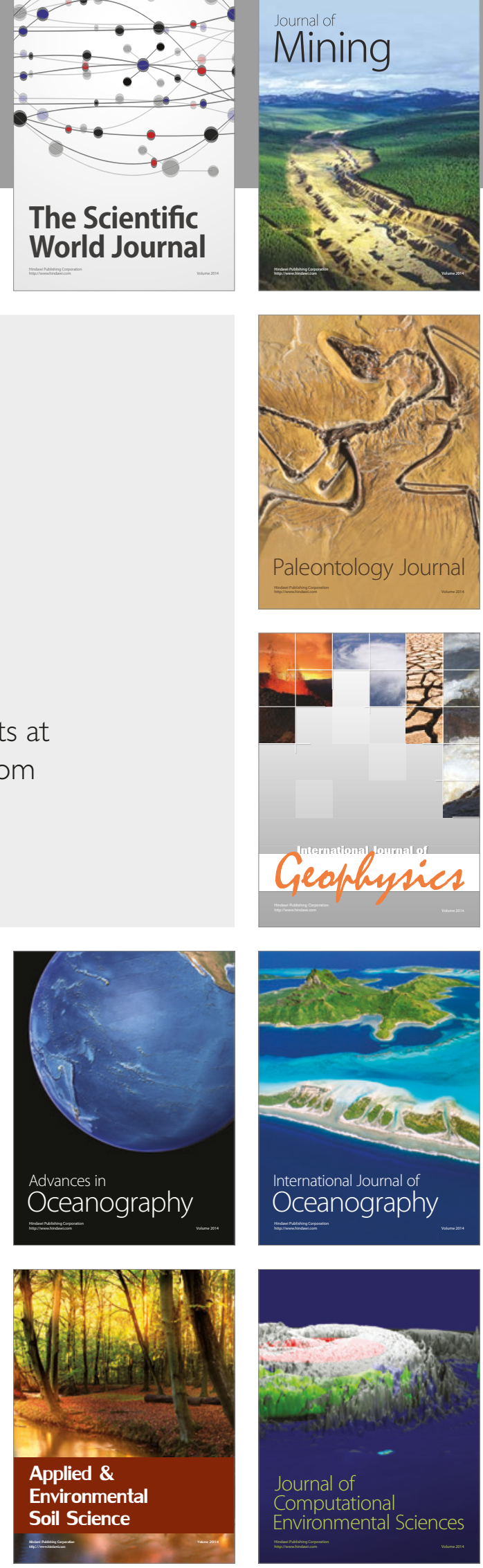